\title{
A Brief Review on Diagnosis of Foot-and-Mouth Disease of Livestock: Conventional to Molecular Tools
}

\author{
Neeta Longjam, ${ }^{1}$ Rajib Deb, ${ }^{2}$ A. K. Sarmah, ${ }^{1}$ Tilling Tayo, ${ }^{3}$ V. B. Awachat, ${ }^{4}$ and V. K. Saxena ${ }^{5}$ \\ ${ }^{1}$ Department of Veterinary Microbiology, College of Veterinary Science, Assam Agricultural University, Guwahati 781022, India \\ ${ }^{2}$ Division of Animal Biotechnology, Indian Veterinary Research Institute (IVRI), Izatnagar 243122, India \\ ${ }^{3}$ Division of Animal Nutrition, Indian Veterinary Research Institute (IVRI), Izatnagar 243122, India \\ ${ }^{4}$ Division of Poultry Science, Central Avian Research Institute (CARI), Izatnagar 243122, India \\ ${ }^{5}$ Division of Veterinary Biochemistry and Physiology, Central Sheep and Wool Research Institute (CSWRI), Avikanagar, India
}

Correspondence should be addressed to Rajib Deb, drrajibdeb@gmail.com

Received 27 December 2010; Revised 25 March 2011; Accepted 20 April 2011

Academic Editor: Suresh Tikoo

Copyright () 2011 Neeta Longjam et al. This is an open access article distributed under the Creative Commons Attribution License, which permits unrestricted use, distribution, and reproduction in any medium, provided the original work is properly cited.

\begin{abstract}
Foot-and-mouth disease (FMD) is one of the highly contagious diseases of domestic animals. Effective control of this disease needs sensitive, specific, and quick diagnostic tools at each tier of control strategy. In this paper we have outlined various diagnostic approaches from old to new generation in a nutshell. Presently FMD diagnosis is being carried out using techniques such as Virus Isolation (VI), Sandwich-ELISA (S-ELISA), Liquid-Phase Blocking ELISA (LPBE), Multiplex-PCR (m-PCR), and indirect ELISA (DIVA), and real time-PCR can be used for detection of antibody against nonstructural proteins. Nucleotide sequencing for serotyping, microarray as well as recombinant antigen-based detection, biosensor, phage display, and nucleic-acid-based diagnostic are on the way for rapid and specific detection of FMDV. Various pen side tests, namely, lateral flow, RT-LAMP, Immunostrip tests, and so forth. are also developed for detection of the virus in field condition.
\end{abstract}

\section{Introduction}

Foot-and-mouth disease (FMD) is a highly contagious disease affecting artiodactylae, mostly cattle, swine, sheep, goats, and many species of wild ungulates [1]. FMD affects extensive areas worldwide and is included in the list of diseases notifiable to the World Organization for Animal Health (http://www.oie.int/eng/en_index.htm). It is recognized as a significant epidemic disease threatening the cattle industry since the sixteenth century and till date it is a major global animal health problem. The history of FMD may be traced to era of Hieronymus Fracastorius, a monk who described a disease outbreak in 1546 A.D. that occurred in cattle near Verona, Italy [2]. Almost 400 years later, in 1897, Friedrich Loeffler and Paul Frosch demonstrated that a filterable agent is responsible for FMD [3]. This was the first demonstration that a disease of animal was caused by a filterable agent and ushered in the era of virology.

FMD generally involves mortality rates below 5\%, but even so it is considered the most important disease of farm animals since it causes huge losses in terms of livestock productivity and trade. Although FMDV rarely causes death in adult animals, the virus can cause severe lesion in the myocardium of young animals, leading to high mortality rates [4-6]. The main constraints in controlling this disease and why it is considered as the most dreaded viral disease are its high contagiousness, wide geographical distribution, broad host range, ability to establish carrier status, antigenic diversity leading to poor cross-immunity, and relatively short duration of immunity. Poor surveillance and diagnostic facilities as well as inadequate control programs are major problems in control of this disease in the country. FMD is still a leading cause of loss of livestock economy in India. Outbreaks are still being reported from time to time around the year [7]. Besides causing direct losses to livestock economy it also causes indirect losses in terms of severe trade restrictions, impact which may be higher than direct losses.

The etiological agent, foot-and-mouth disease virus (FMDV) is classified within the genus Aphthovirus in the family Picornaviridae [8]. The virus exists in the form of 
seven serologically and genetically distinguishable types, namely, O, A, C, Asia1, SAT1, SAT2, and SAT3, but a large number of subtypes have evolved within each serotype [9]. Serotype $\mathrm{O}$ and A reported in France by Valee and Caree [10] and in 1926, Waldmann and Trautwein [11] reported serotype C. Serotypes SAT1, SAT2, and SAT3 of FMDV was observed in sample collected from the FMD outbreak in South Africa. The seventh serotype, Asia 1, was reported from Pakistan [12].

FMDV is a single stranded (ss) positive sense RNA virus with the whole virus particles having sedimentation coefficient of $146 \mathrm{~S}$ [13] and genome of $\sim 8.5 \mathrm{~Kb}$ size. The genome is polyadenylated at $3^{\prime}$ end and carries a small covalently linked protein, VPg at $5^{\prime}$ end [13]. The $5^{\prime}$ untranslated region (UTR) contains a short fragment called S-fragment, a poly (C) tract followed by large (L) fragment of over 700 bases. Functionally, the genome can be categorized into three main regions: (a) $5^{\prime}$ noncoding regulatory region, (b) polyprotein coding region (subdivided into L, P1, P2, and P3), and (c) $3^{\prime}$ noncoding regulatory region. The translation initiation starts at two AUG codons separated by 84 nucleotides following the Internal Ribosome Entry Site (IRES). The viral genome is translated as a single polyprotein, which is posttranslationally cleaved by viral proteases [14] into four structural proteins (VP1, VP2, VP3, and VP4) and several nonstructural proteins (L, 2A, 2B, 2C, $3 \mathrm{~A}, 3 \mathrm{~B}, 3 \mathrm{C}$, and 3D) [15]. The $\mathrm{P} 1$ region of genome encodes the 4 structural proteins VP1, VP2, VP3, and VP4 encoded by $1 \mathrm{D}, 1 \mathrm{~B}, 1 \mathrm{C}$ and $1 \mathrm{~A}$ genomic regions, respectively, [13]. Sixty copies of each structural protein (VPl-4) assemble to form the capsid [13]. Among which VP4 is internal whereas others are exposed on virion surface [16]. The 3 surface exposed capsid proteins carry the neutralizing antigenic sites [17]. Among the 4 structural polypeptides, VP1 is the most immunogenic protein of FMDV [18] having its G-H loop protruded from the surface [19], and is maximally exposed on the capsid surface $[16,20]$ forming large part $(54 \%)$ of virus surface [21].

Although, the disease has been controlled successfully in many parts of the world by regular vaccination of susceptible animals and slaughtering of infected animals, no country has been considered safe, because of the highly contagious nature and rapid spread of the infection [22]. For the effective control of the disease, outbreaks should be detected at an early stage and persistent infections should also be recognized to prevent further transmittance. These can be achieved when vaccination is regular and effective and when diagnostic tools available are specific and sensitive and at the sametime rapid.

Lots of work has been carried out to develop and validate diagnostic tests in regard to this disease. Conventional techniques such as complement fixation test (CFT) [23], serum neutralization tests (SNT) [24] and enzyme-linked immunosorbent assay (ELISA) [25] are still in use for the routine detection of FMDV in clinical samples. Sandwich ELISA is being carried out for the detection of specific FMDV antigens in epithelial tissue suspensions which is usually accompanied by concurrent cell culture isolation and the application of ELISA to any samples showing a cytopathogenic effect [26]. Virus isolation in primary cultures is laborious, expensive, and requires days/weeks (cell passages) before the results are obtained [27]. However, with the introduction of molecular techniques in the field of diagnosis, several techniques based on viral genome detection such as hybridization using DNA probes [28] and the advent of Polymerase Chain Reaction (PCR) technique in the recent past have led to development of several reverse transcription PCR (RT-PCR) procedures for specific detection of FMDV RNA [29-34]. Because of the reported sensitivity and specificity, RT-PCR has been evaluated as a diagnostic tool for FMDV detection in parallel with ELISA and virus isolation [35]. Another form of PCR, multiplex PCR (mPCR), has also been evaluated for differentiating FMDV serotypes $[27,36,37]$ as well as for differential diagnosis with other vesicular diseases such as Vesicular' Stomatitis, Swine Vesicular Disease [38]. The most recent development in the field of diagnosis by nucleic acid detection is the use of thermal cyclers capable of measuring fluorogenic PCR amplification in real-time have become available, making precise quantitation of nucleic acids possible over a wide concentration range. The fluorogenic RTPCR provides relatively fast result, enables a quantitative assessment to be made of virus amount, and can handle more samples and/or replicates of samples in a single assay than the conventional RT-PCR procedure [39].Therefore it is seen as a valuable tool to complement the routine diagnosis procedure for FMD virus diagnosis.

Currently, the FMD diagnosis in our country (India) is being carried out using techniques developed at Project Directorate on FMD (PD FMD), Mukteswar which includes Virus isolation (VI), Sandwich-ELISA (S-ELISA), LiquidPhase Blocking ELISA (LPBE), Multiplex-PCR (mPCR) and recently DIVA test which is an indirect ELISA for detection of antibody against nonstructural proteins. LPBE is being used for the detection of antibody titers against the FMD vaccinated animals. The S-ELISA is being used for the antigen detection using the material from the lesions but because of its low sensitivity currently mPCR is being used. The real-time PCR-based detection method is used in the many reference laboratories in the world for the purpose [7].

\section{Etiology and Molecular Organisation of the Virus}

Foot-and-mouth disease virus (FMDV) was the first recognized viral pathogen [40] and is the sole member of the genus Aphthovirus belonging to the Picornaviridae family. Seven immunologically different serotypes of the FMD virus are known, namely, A, O, C, Asia-1, South-African Territories (SAT) $-1,-2$ and -3 , which comprise more than 65 subtypes. Initially 2 types were named: type $\mathrm{O}$ for Oise in France and type A for Allemagne (Germany) [10]. Later type C was recognized as an additional type in Germany [11]. Some 30 years later, work at Pirbright laboratory in England demonstrated 3 novel serotypes of FMDV in sample collected from the FMD outbreak in South Africa and called SAT1, SAT2, and SAT3. The seventh serotype, that is, Asia 1 was first recognized in a sample from Pakistan [12]. 
The viral particle, or virion, contains a single-stranded RNA of positive polarity, approximately 8500 nucleotides long. It is an icosahedral particle with a smooth surface and a diameter of about $30 \mathrm{~nm}$ [13]. The fine structure of the virus has been described by X-ray crystallography $[16,41,42]$. There are 60 copies of each of the structural protein VP1, VP2, VP3, and VP4. While the first three structural proteins $(\mathrm{MW} \approx 24 \mathrm{kDa}$ ) have surface components, the fourth $(\mathrm{MW} \approx 8.5 \mathrm{kDa})$ is internal. The virion is also usually composed of one or two units of VP0, the precursor of VP2 and VP4 [16, 43]. The structural proteins, VP1-3 fold into an eight-stranded wedge-shaped 13-barrel which fits together to form the majority of the capsid structure [16]. The three-dimensional structure of FMDV has revealed a prominent surface feature formed by the loop between the $\mathrm{G}$ and $\mathrm{H}$ strands of VP1. The VP4 protein is located inside the capsid [44]. The strands of the 13-barrel of VP1-3 are connected by loops which form the outer surface of the virion [45]. Unlike other picornaviruses, FMDV lacks a surface canyon or pit which is the receptor binding site for entero- and cardioviruses [46]. Another feature of the virion is the channel at the fivefold axis which permits the entry of small molecules such as Cscl into the capsid resulting in FMDV having the highest buoyant density of the picornaviruses [42].

The main cell attachment site and the immunodominant region of FMDV are both located on a solvent exposed region at the surface of the virion, namely, in trypsin-sensitive areas of VP1 $[47,48]$. Earlier serological studies showed that different serotypes of FMDV shared a highly variable region of VP1, comprising residues 135 to 155 [49], as one of the major antigenic sites of the virus.

The genome of FMDV is about $8.5 \mathrm{~Kb}$ in length enclosed within a protein capsid. It has four major parts: $5^{\prime}$ Untranslated region ( $\left.5^{\prime} \mathrm{UTR}\right)$, Coding region, $3^{\prime}$ Untranslated region ( $\left.3^{\prime} \mathrm{UTR}\right)$, and a poly "A" tail. The $5^{\prime} \mathrm{UTR}$ is linked with Vpg (3B) which serves as primer in replication. 5'UTR contains an $\mathrm{S}$ fragment at its $5^{\prime}$ end which encompasses 360 bases, folds into long stem loop and plays a role in genome stability and the binding of protein involved in genome replication [50]. Following $\mathrm{S}$ fragment there is poly " $\mathrm{C}$ " tract comprising over $90 \%$ " $\mathrm{C}$ " residues. The length of this tract is extremely variable [51]. There are some evidences that length of this tract is associated with virulence and hence persistence [52]. After poly " $\mathrm{C}$ " tract, there is a series of RNA pseudo knot structures of unknown function [53]. Downstream to the pseudo knot there is cisacting replicative element (cre) [54]. The cre has conserved AAA sequences and is essential for genome replication [54]. Downstream to cre is internal ribosomal entering sites (IRES). The IRES has role in initiation of viral protein synthesis and shutting down of host cell protein synthesis [53]. Due to the presence of IRES, picornaviruses are able to bind to ribosomes to initiate the protein synthesis. The picornaviruses have no $5^{\prime}$ cap (7-methyguanosine), so IRES serves as ribosomal entering site [55]. The $3^{\prime}$ UTR follows the ORF (open reading frame) termination codon and contains a short stretch of RNA which folds into specific stem loop structures [56] followed by a poly "A" tract of variable length [57]. This $3^{\prime}$ UTR also serves as some functions in genome replication [58]. $3^{\prime}$ UTR is specific for each picornavirus. Poly "A" probably plays a role in FMDV translation [59] and replication [60]. The FMDV genome encodes a polyprotein from which four different structural and eight different non-structural proteins are formed by the viral proteases. After translation, the four primary cleavage products are formed: (i) the amino terminal $\mathrm{L}$ protease which cleaves at its own carboxy terminus, P1-2A, (ii) the precursor of the capsid proteins (iii) $2 \mathrm{BC}$, and (iv) $\mathrm{P} 3$ which is cleaved to make the NSPs [61]. FMDV has two proteinases. The NSP leader proteinses (Lpro) located in the $\mathrm{N}$-terminal region of the polyprotein acts both intra and intermolecularly. This protease initiates cleavage by separating itself from $\mathrm{P} 1$, the precursor of the capsid protein and the remainder of the growing polypeptide chain [62]. The 3C protease is responsible for the cleavage of $\mathrm{P} 1$ into $1 \mathrm{AB}$ (VP0), 1C (VP3), and 1D (VP1). The 1A/1B (VP4/VP2) cleavage occurs at the late stage in virus morphogenesis and is associated with maturation of capsid. The $2 \mathrm{C} / 3 \mathrm{~A}$ primary cleavage is cis and subsequent cleavage is also mediated by the 3Cpro and producing processing intermediates and mature proteins [63]. In addition to viral protein processing, the 3Cpro cleave the host cell protein histone $\mathrm{H} 3$ and may be involved with the shuting down of host cell transcription [64]. The cleavage between $2 \mathrm{~A} / 2 \mathrm{~B}$ junctions is mediated by $2 \mathrm{~A}$ polypeptide separating itself and $\mathrm{P} 1$ away from $2 \mathrm{BC} / \mathrm{P} 3$ [61]. This change is independent of both $\mathrm{L}$ and $3 \mathrm{C}$. The FMDV 2A region is very short (about 18 amino acids) and together with the $\mathrm{N}$ terminal residues of protein $2 \mathrm{~B}$, represents an autonomous element capable of mediating cleavage at its own $\mathrm{C}$ terminus [65].

\section{Epidemiology of the Disease}

FMD is a highly transmissible disease, and a limited number of infective particles can initiate host infection [66]. Contaminated animal products, nonsusceptible animals, agricultural tools, people, vehicles, and airborne transmission [67] can contribute to the mechanical dissemination of FMDV. The epidemiology of FMD is complex, and it is affected by different viral, host, and environmental factors, among them, variations in virus virulence (severity of lesions, amount, and duration of virus release), particle stability in different microenvironments, and chances of long-term persistence. FMDV multiplication and spread also depend on the host species, nutritional and immunological status, population density, animal movements, and contacts between different domestic and wild host species and animals capable of mechanical dissemination of the virus [68]. The environment can provide geographical barriers to virus dissemination or, alternatively, can promote virus transmission when appropriate atmospheric conditions prevail. In this multifactorial scenario $[69,70]$, the high potential for FMDV variation and adaptation has modelled complex evolutionary patterns that are being revealed by molecular epidemiology analyses, mostly based on nucleotide sequencing of capsid protein genes. 
Of the different serotypes prevalent in India, type "O" has been found to be predominant over other types [7177]. Similarly in the North-Eastern region of India, the frequency of FMD is highest with type " $\mathrm{O}$ ", which is always followed by other types including the type "Asia-1" $[78,79]$. The agroclimatic and socioeconomic condition, mixed animal husbandry practices, unrestricted movement, and trade among animals and porous international border provide a conductive epidemiology niche for the FMDV to flourish, mutate, and persist over time and to affect the susceptible animal population $[80,81]$.There are records of about 5,000 outbreaks to occur in India annually affecting nearly three lakh animals [82] with an estimated staggering loss of Rs. 4,300 cores to the economy annually [83].The losses are mainly due to reduction in milk yield, draught power, and breeding capabilities. In India where world's largest livestock populations exist, it is a leading cause of loss of livestock economy (direct and indirect losses) due to its endemic nature.

\section{Pathological Aspect of FMD}

Foot-and-mouth disease (FMD) is an acute systemic infection affecting even-toed ungulates, both domesticated and wild, including cattle, swine, sheep, and goats. Beside domesticated animals, other animals species affected with FMD includes elephant [84], mithun [85, 86], yak [87], sambar, spotted deer, and wild buffalo $[87,88]$.

FMDV produces an acute, systemic vesicular disease, which requires a differential diagnosis from other vesicular diseases [89]. In natural infection, the main route of virus entry is the respiratory tract. The initial virus multiplication usually takes place in the pharynx epithelium, producing primary vesicles, or "aphthae" [90]. The vesicles produced by FMDV generally affect cells from the epithelial stratum espinosum. The clinical outcome of the disease may vary among the host species considered and the infecting virus strain. In cattle and pigs, fever and viraemia usually start within $24-48 \mathrm{hr}$ after epithelium infection, leading to viral spread into different organs and tissues and the production of secondary vesicles preferentially in the mouth and feet. The acute phase of disease lasts about 1 week and declines gradually coinciding with the emergence of a strong humoral response [91]. The morbidity and mortality in FMD depends upon the breed and age of the animal where mortality in adult animals is very low (two per cent) in comparison to 20 per cent in young stock [92]. The calves show prominent signs of myocarditis, whereas piglets manifest gastroenteritis [93]. In sheep and goats, symptoms are frequently less severe and may make the detection of the disease difficult [94].

Asymptomatic, persistent infection can also be established in ruminants, during which infectious virus can be isolated from the oesophagus and throat fluids of the animals from a few weeks up to several years of the initial infection. There is epidemiological evidence to support the hypothesis that carrier animals may be the origin of outbreaks of acute disease when brought into contact with susceptible animals. This mode of transmission has been experimentally reproduced for serotype SAT isolates [95].

\section{Diagnosis of FMD}

The accurate diagnosis of infection with FMDV is of prime most importance for both control and eradication campaigns in FMD endemic areas and as a supportive measure to the stamping out policy in FMD-free areas [96]. The history of research and diagnosis in foot-and-mouth disease falls into several distinct areas. The search for experimental laboratory animals, producing the disease culminated in the demonstration by Waldmann and Pape [97], the susceptibility of the guinea pig, and the suckling mouse by Skinner in 1951. Early work by Hecke and the Maitlands in the early 1930s, followed by the crucial demonstration by Frenkel in 1947 that large amounts of the virus could be produced in surviving tongue epithelium, formed the basis for the vaccination programmes initiated in Europe in the 1950s [98]. The subsequent development of cell lines has brought a remarkable degree of sophistication to the study of virus growth. The recognition of more than one serotype has led to the development of various techniques for serotyping of the virus. As early as 1927, Bedson et al. found that two isolates of a serotype "A" virus could be differentiated by cross-neutralization tests [99]. Earlier typing of FMDV was done by cross-immunity test in guinea pigs [11] and less frequently in cattle [13]. As this test was time consuming, expensive, and imprecise [100], different serological tests like complement fixation test (CFT), virus neutralization test (VNT), and enzyme-linked immunosorbent assay (ELISA) were developed and the most recent is the development of molecular techniques, the polymerase chain reaction (PCR) method making diagnosis more rapid and precise. Presently we have demonstrated that multiplex PCR could detect FMD virus in the highest number of samples $(65.47 \%)$ followed by sandwich ELISA (53.57\%) and virus isolation (42.85\%) [101].

5.1. Complement Fixation Test (CFT). In 1929, Ciuca was first to use CFT for typing antiserum and FMDV of guinea pig origin [13]. Later, virus of bovine origin was successfully typed by CFT using guinea pig antiserum [23]. Since then CFT has been used extensively for distinguishing different strains of FMDV [24, 102, 103]. Subsequently, a modification of CFT, micro-CFT was developed, in which 96 well microtiter plates were used instead of tubes [104]. In the years 1964-1965 CFT (tube test) was used to replace the virus type identification by guinea pig cross-protection test [105]. Subsequently, the micro-CFT was adopted for this purpose $[106,107]$. Although CFT was a fast method it needed high virus load and results were sometimes affected by pro-and anticomplementary activities of the test sample [26].

5.2. Virus Isolation. Primary cell culture of bovine [108$110]$, ovine and porcine [111] origin has exhibited susceptibility to FMDV from infected tissues. However, the most sensitive culture system for virus isolation is primary bovine thyroid cells [109] but cryopreservation of bovine thyroid cells directly after trypsinization results in the loss of susceptibility to FMDV [110]. Some stable cell lines, like IBRS-2 [112], MVPK-1 clone 7 [112, 113], LFBK cell line and 
BHK-21 [114] are also susceptible to FMDV and so are most desirable for diagnostic system but these are less sensitive than primary cells for detecting low amount of infectivity [115].

Revenson and Segura [116] reported that FMDV grew well on BHK-21 cell line enabling large-scale production of antigen with good complement fixing properties. The BHK21 cell culture provides better growth for FMDV than the suspension culture $[115,117,118]$. It has also been reported that with subsequent passage in BHK-21 clone 13 cell line, the titre of FMDV increased significantly [108]. Nair [112] reported that the susceptibility and infectivity titers of IBRS2 and MVPK cell lines were less as compared to BHK-21 cells, and thus had no advantage over BHK-21 cell line for vaccine production. Mishra et al. [119] also adapted FMDV field isolates to BHK-21 clone 13 cells in 3-7 serial passage.

Goel and Rai [120] reported that the field isolates of FMDV could be passaged in BHK21 clone 13 monolayer cell culture, which showed characteristic CPE and were readily adapted between 3rd and 5th passage. The CPE usually develops within 48 hours, if no CPE is detected the cells should be frozen and thawed, used to inoculate fresh cultures and examined for CPE for another 48 hours. An alternative to the virus isolation is cell suspension plaque test which also quantify the virus present in sample [121]. However, the cell culture system is laborious, time consuming, and relatively low sensitive. It also requires careful handling of specimens and a biosafety laboratory.

The availability of cell culture techniques and the realization that FMDV can be grown in in vitro cultured cells made possible the adaption of neutralization test for routine type identification of FMDV isolates and were found to be more specific than CFT [100]. In particular, virus isolation requires a laboratory cell culture facility, which can be difficult and expensive to maintain, besides requiring 4 to 6 days for test completion [122]. Subsequently microneutralization test (MNT) was used for the assessment of antigenic variation in field strains, as it correlated well with cattle protection test $[123,124]$. But it was observed that, minimal heterotypic contamination in the sample could interfere with precise type identification of the virus [24]; on the other hand VN test depends on tissue culture and is more prone to variability than ELISA and also require biocontainment facilities.

\subsection{Enzyme-Linked Immunosorbent Assay (ELISA). ELISA} came into use as diagnostic methods for many infectious diseases around the year 1975; till then it has been used as one of the most accepted serological techniques. The first report of use of an indirect ELISA to screen cattle for antibodies against FMDV was that of Abu Elzein and Crowther [125]. Subsequently, a sandwich ELISA using convalescent bovine immunoglobulin (Igs) as capture and anti-146S guinea pig sera as tracing sera was found suitable for detection and quantification of FMD virus in infected tissue culture fluid and epithelial tissue samples [126]. The use of anti-146S rabbit immunoglobulin in place of convalescent bovine immunoglobulin as capture antibody increased the sensitivity of sandwich ELISA [127].
Later ELISA and its various modifications were applied for detection, typing, and strain differentiation of FMDV isolates with better sensitivity than CFT and, the results were comparable to that obtained with MNT [25, 125, 128-134]. Liquid phase blocking ELISA using bovine convalescent sera for characterization of field isolates was done and result tallied with conventional VNT [135-137]. ELISA results were much more reproducible than those obtained with VNT and are not influenced by variations in tissue culture susceptibility. At the FAO/WRL for FMD, the preferred procedure for the detection of FMDV antigen and identification of viral serotypes is ELISA $[26,138]$. The results can be obtained within 3-4 hours after sample is received by the laboratory; a negative sample is confirmed by inoculation of sample into sensitive cultures followed by confirmation of the virus serotype by ELISA. Indirect ELISA was initially used for detection of FMDV antigen in infected cell culture fluid, mice carcass, and cattle tongue as well as antibodies in sera samples $[129,133]$. Later a sandwich ELISA was used for subtype analysis of FMDV isolates [134]. Subsequently, a sandwich ELISA was developed for detection and typing of FMDV directly from field materials [139]. Although ELISA is far finer to CFT, a large number of samples failed to give positive results and such negative sample has to be confirmed by inoculation of sample into sensitive cultures [140] followed by confirmation of the virus serotype by ELISA taking 4 more days, a time frame compatible with the need to rapidly detect disease and initiate and appropriate disease control strategy. As a consequence, there is a need of an alternative assay system that allows more rapid confirmation of clinical diagnosis with more sensitivity and this has resulted in development of polymerase chain reaction (PCR) or the more recent real-time PCR.

5.4. Reverse Transcription-Polymerase Chain Reaction (RT$P C R$ ). Polymerase chain reaction was the most widely use nucleic-acid-based diagnostic techniques since its invention [141, 142]. With the development of RT-PCR to amplify RNA targets many workers have assessed the usefulness of it as a reliable tool for FMD diagnosis [29, 30, 32, 33] and in parallel with conventional assays [34, 143, 144]. A particularly high sensitivity was reported by RT-PCR ELISA $[143,145]$. A specific RT-PCR was developed and validated for the detection of the polymerase gene (3D) of FMD with an analytical sensitivity equal to 1000 times higher than that of a single passage virus isolation [146]. In a study to compare the sensitivity of assays for the diagnosis of FMD, a cell suspension plaque test on BHK21-CT cells and a reverse transcription nested PCR (RT-nPCR) were used to examine nasal swabs and probang samples obtained from FMDV infected cattle, it has been observed that examination of nasal swab revealed a higher number of infected animals using RTnPCR than by the used the plaque tests and for probang samples both test gave approximately equivalent result [147]. PCR products generated have currently only been analyzed by gel electrophoresis exposing to the chance of post-PCR contamination. However PCR offers potential advantages over other conventional tests. The risk of false negative associated with poor sample handling is limited. Because 
virus, if present, would be inactivated by RNA extraction, it would be acceptable to use lower level biosafety. Further, cell culture loses the sensitivity due to presence of inhibitors like interferons and presence of some enzymatic inhibitors. Several studies have compared Reverse Transcription (RTPCR) methods with FMDV isolation [35, 143, 147-149]. The sensitivity of the methods reach similar to or greater than virus isolation techniques and these can supplement or go in parallel, but not replace, the routine procedures for diagnosis of FMDV. Detection of all seven serotypes of the virus with each of the serotype specific primers in selected RTPCR protocols at OIE/FAO World Reference Laboratory for FMD (WRL), Pirbright demonstrated suitable specificity and detected cell culture passage isolate with some success but were not adequate for the serotyping of suspension prepared from clinical samples of epithelium. RT-PCR though has paved the way to more sensitive and rapid test in the field of molecular diagnosis, serotyping of FMDV has been of difficult and this has been solved with the advent of multiplex PCR (mPCR).

5.5. Multiplex Polymerase Chain Reaction (mPCR). To overcome the inherent disadvantage of cost and to improve the diagnostic capacity of the test, multiplex PCR, a variant of the test in which more than one target sequence is amplified using more than one pair of primers, has been developed. This modified technique was originally developed to detect distinct/genetic alterations in large regions of human genome. Afterwards, mPCR was used for the detection and differentiation of multiple pathogens/different strains of the same pathogen. It has additional advantages such as costeffectiveness and rapidity. There are reports on the use of mPCR for differential diagnosis of FMDV serotypes [27, 36]. One such PCR [36] was evaluated in WRL FMD Pirbright and found to work on tissue samples with limited success [148]. To improve the overall diagnostic sensitivity and to provide tools for serotyping FMDV, multiplex PCR arrays have been developed to detect FMDV in infected tissue and food samples [150].

The concept of using multiplex PCR to detect FMDV and its serotypes has also been examined by others [151, 152]. An advantage of multiplex PCR systems, compared with probebased assays, is that the intrinsic design does not rely on a probe for a single conserved gene or region of the genome. Rather, the multiplex system is designed to survey multiple regions of the genome simultaneously, thereby increasing the probability of detection [153]. To date, these mPCR assays are limited to partial serotyping of FMDV because no existing multiplex PCR assay offer complete coverage for all seven serotypes [154]. Multiplex PCR for differential diagnosis of various vesicular diseases like Vesicular Stomatitis, Swine Vesicular Disease, Vesicular Exanthema, and FMDV have also been described [38, 155]. Recently, mPCR for differentiation of Indian FMDV serotypes has been developed and evaluated on tongue epithelium and cell culture samples [37]. In the earlier studies, we have showed that multiplex PCR are more sensitive than sandwich ELISA and virus isolation for detection of FMDV from clinical materials [101].
5.6. Real-Time Polymerase Chain Reaction. The use of polymerase chain reaction (PCR) in molecular diagnostics has increased to the point where it is now accepted as the gold standard for detecting nucleic acids from a number of origin and it has become an essential tool in the research laboratory [156]. The potential of this format to provide sensitive, specific, and swift detection and quantification of viral RNAs has made it an indispensible tool for state-of-the-art diagnostics of important human and animal viral pathogens [157]. Real-time PCR has engendered wider acceptance of PCR due to its improved rapidity and sensitivity [156] overcoming poor precision, low sensitivity, low resolution, absence of automation, only size-based discrimination, absence of expression of results in numbers, poor quantitative performance (Ethidium bromide for staining is not very quantitative), and post-PCR processing, rendering the conventional PCR not very suitable for accurate diagnosis.

There are currently five main chemistries used for the detection of PCR product during real-time PCR. These are the DNA-binding fluorophores, the $5^{\prime}$ endonuclease, adjacent linear and hairpin oligoprobes, and the selffluorescing amplicons [156]. This approach is a highly sensitive technique enabling simultaneous amplification and quantification of specific nucleic acid sequences. In addition to enhanced sensitivity, the benefits of real-time PCR assays over conventional endpoint detection methods include their large dynamic range, a reduced risk of cross-contamination, an ability to be scaled up for high-throughput applications and the potential for accurate target quantification [158160]. Real-time PCR assays recommended by the World Organization for animal health (OIE) for detection of FMDV incorporate universal primers and fluorescent-labeled probes that recognized conserved region within the $5^{\prime}$ UTR [39] or conserved gene regions within the RNA-dependent RNA polymerase gene (3Dpol) [161]. The use of a specific probe facilitates an increase in specificity compared to conventional agarose-gel-based PCR assays [162, 163].

Recently, TaqMan technology has combined the $5^{\prime}$ nuclease activity of the Taq DNA polymerase and forster resonance energy transfer to detect and quantify amplification product in a closed tube format. Using this technology real-time PCR has been developed to detect the nucleic acid $[164,165]$. This is most sensitive and rapid method to detect the nucleic acid. The viral RNA can be consistently detected over a seven log range, the lowest of which corresponded to as few as 10-100 RNA per volume tested. The test can be performed in 2 hours or less on a portable instrument and sample can be held at ambient temperatures. Real-Time chemistry allows for the detection of PCR amplification during the early phases of the reaction and as the name suggest, realtime PCR monitors the progress of a PCR reaction in the real-time. At the same time, a relatively small amount of PCR products (DNA, CDNA, or RNA) can be quantified. Measuring the kinetics of the reaction in the early phases of PCR provides a distinct advantage over traditional PCR detection. Traditional methods use agarose gels for detection of PCR amplification at the final phase or end point of the PCR reaction which is associated with considerable hands on time, posses a serious hazard for amplification product 
carryover, and limits the number of specimen that can be processed simultaneously. It is hard to differentiate the 5 fold changes on gel whereas real-time PCR is able to detect even twofold changes (e.g., 10 versus 20 copies). In addition to the widely exploited $5^{\prime}$-nuclease (TaqMan) system using duallabelled probes $[39,161,166]$ and modified MGB probes [167], assays have also been developed using other rRT-PCR formats such as those using hybridization probes [146] and PriProET [168].

The greatest problem facing the diagnostic application of PCR is the production of false positive results. They are attributable to contamination by nucleic acids, particularly from the previously amplified material (carry over). Any contaminant, even the smallest airborne remnant carried over from the previous PCR procedure or from a strongly positive sample (contamination), may be multiplied and produce a false positive results. In the Real-time PCR, the problem of carry-over is significantly reduced because of the real-time measuring principle, which is based on closed tube system. In order to increase assay throughput and minimise operator errors, real-time PCR assays for FMDV have also been automated using robots for nucleic acid extraction and liquid handling equipment to setup the reaction mixes [146, 169]. The assay has also been applied for FMDV and it is capable of detecting all seven serotypes [39, 161, 169-177]. First interassay/laboratory equivalence investigation [178], participated by five European reference laboratories for detection of FMDV has observed that the best of the Real-Time PCR assays used in each laboratory gave comparable results unlike the VI results which were highly variable. Performance of three real-time instruments: the LightCycler.2 (Roche), the SmartCycler I I (Cepheid), and the SDS 7900HT (AB) was compared for detection of FMDV and has successfully identified the FMDV genome and beta actin mRNA from several sources of infected nasal and oral swabs, as well as probang samples [167]. In addition to extensive testing of vesicular epithelium samples, the performance of rRT-PCR has recently been assessed on milk [179] and "probang" samples [180]. Automated real-time RT-PCR has been compared with VI and antigen-detection ELISA with result being more positive by real-time PCR indicating that the real-time PCR has higher sensitivity than VI for the detection of FMDV in epithelial samples [181].

The development of multicolour real-time PCR cyclers and "ready-to-use" commercial multiplex real-time PCR kits has also made it possible to combine several assays within a single tube. Major advantages of multiplexing include a reduced sample requirement, which is especially important when sample material is scarce $[182,183]$, and the ability to combine assays with an internal control system. However, it is important to optimize these assays in order to limit competitive interactions that may significantly impact upon assay sensitivity. The combined properties of high sensitivity and specificity, low contamination risk, and speed have made real-time PCR technology a highly attractive alternative to tissue culture- or immunoassaybased methods for diagnosing many infectious diseases [184]. Clinical diagnostic applications and the use of realtime PCRs are growing exponentially, and real-time PCR is rapidly replacing conventional PCR and other established diagnostic methods such as antigen-ELISA and cell culture isolation.

5.7. Recombinant Antigen-Based Diagnosis. The $3 \mathrm{AB}$ protein of FMDV was expressed in E. coli [185-187] or in P. pastoris [188] and has been used for the diagnosis of FMD infection in cattle. Similarly, $3 \mathrm{ABC}$ proteins expressed in heterologous systems were used in ELISA (3ABC ELISA) for serodiagnosis of FMD [189, 190]. Further, four serotypes of FMDV structural proteins expressed in P. pastoris and its potential utility either as immunogen or antigen has been successfully assessed in animal model [191-193]. A recombinant FMDV polyprotein (P1) with 3C expressed in insect cells was evaluated for detecting antibodies to FMDV serotype Asia 1 in ELISA and has the potential to replace the liquid phase blocking (LPB)-ELISA using an inactivated FMDV antigen as a simple and robust serological tool for screening antibodies to FMDV serotype Asia 1 [194].

5.8. DIVA-Based Companion Diagnostic Approach. The ability to identify and selectively delete genes from a pathogen has allowed the development of "marker vaccines" that, combined with suitable diagnostic assays, allow differentiating infected from vaccinated animals (DIVA) by differentiation of antibody responses induced by the vaccine (no antibodies generated to deleted genes) from those induced during infection with the wild-type virus [195].

A number of antigenic non-structural proteins (NSPs) of FMD were identified and out of which $3 \mathrm{ABC}$ gene appears to be the most reliable marker of FMD virus replication $[196,197]$. The deletion of NSP (3ABC) gene has been used for enabling DIVA approach for FMD (Cedivac-FMD inactivated vaccine). For detection of NSP antibodies, the Ceditest FMD-NS ELISA is commercially available. Indirect ELISA test for the detection of antibodies against nonstructural proteins will play an essential role in the serological survey of livestock herds in future postoutbreak situations. It has been demonstrated that protection against footand-mouth disease (FMD) could be achieved following vaccination with chimeric foot-and-mouth disease virus (FMDV) vaccines, in which the VP1 G-H loop had been substituted with that from another serotype. This indicated that the VP1 G-H loop may not be essential for the protection of natural hosts against FMDV. If this could be substantiated there would be potential to develop FMD marker vaccines, characterised by the absence of this region [198]. A mutant FMDV with deletion of immunodominant epitopes was evaluated to use as a marker vaccine recently, In that study, a B-cell epitope was identified in the $3 \mathrm{~A}$ region of a nonstructural protein (NSP) by anti-FMDV cattle sera and a recombinant FMDV (rvAs-3A14D) was generated by selectively deleting 14 amino acids (position 91-104) in the $3 \mathrm{~A}$ region of the NSP. Following in vitro transcription and transfection in BHK-21 cells, the rvAs-3A14D was rescued from BHK-21 cells. Characterization of the rvAs-3A14D revealed that the infectivity, antigenecity, and replication kinetics in BHK21 cells and virulence in mice of the rvAs3A14D were similar to that of its parent virus. Those data 
suggested that the recombinant FMDV with deletion of this epitope in the NSP may be potentially used as a candidate inactivated vaccine and therefore, the application of the marker vaccine and differential diagnostic tests may open a promising new avenue for the development of a vaccine for DIVA.

5.9. Microarray-Based Diagnosis of FMDV. DNA microarrays are becoming increasingly useful for the analysis of gene expression and single nucleotide polymorphisms (SNPs) [199-201]. The application to discriminate among variants of FMDV is added to a number of microarray procedures used in virology to analyze multiple viral pathogens that belong to different virus families [202], to detect specific viruses $[203,204]$ or to define genetic variations undergone by viruses $[205,206]$.

The distinction among mutants of the same virus is becoming increasingly necessary in view of the extensive variation among representatives of most virus groups [207], the quasispecies population structure of RNA viruses and some DNA viruses [208], and the increasing recognition that one or a limited number of mutations in a viral genome can have a profound effect in its biological behavior [209, 210].

Baxi et al. [211] developed a microarray-based test that used a FMD DNA chip containing 155 oligonucleotide probes, 35-45 base pairs (bp) long, and serotype-specific, designed from the VP3,VPl-2A region of the genome. A set of two forward primers and one reverse primer were also designed to allow amplification of approximately $1100 \mathrm{bp}$ of target sequences from this region. The amplified target was labelled with Alexa-Fluor 546 dye and applied to the FMD DNA chip. A total of 23 different FMDV strains representing all seven serotypes were detected and typed by the FMD DNA chip. Microarray technology offers a unique capability to identify multiple pathogens in a single chip [211].

It was documented that DNA microarray technology can be used as a high-throughput method to analyze polymorphisms within a short region of the FMDV genome and have successfully devised a SVM-based method to classify the samples on the basis of their hybridization signal and to detect SNPs at a major antigenic site of the virus [212].

5.10. Biosensors for Detection of FMDV. An immunobiosensor using a piezo electric (PZ) crystal was developed and standardized for foot- and- mouth disease (FMD) diagnosis and virus typing [213]. Allosteric biosensors allow detection of antibodies against different viruses by accommodating peptide sequences from surface viral proteins, acting as antibody receptors, into permissive sites of allosterically responsive recombinant $\beta$-galactosidases. Among the advantages of such biosensors as diagnostic tools is the homogeneous nature of the assay, the short time required for the enzymatic reaction and antibody detection, and the potential for handling large number of samples and for automatic processing, as shown for human immunodeficiency virus $[214,215]$. In the serological diagnosis of infectious diseases, the use of allosteric biosensors, namely, hybrid enzymes that respond enzymatically to antibodies directed to foreign peptides displayed on the enzyme surface [216, 217], is highly promising [218]. Multiple insertions of a major FMDV Bcell epitope from the VP1 capsid protein near the active site of recombinant $\beta$-galactosidases dramatically increased the enzyme responsiveness to specific antipeptide antibodies, including sera from infected animals $[219,220]$. It has been reported that recombinant $\beta$-galactosidases accommodating one or two different peptides from the FMDV NS protein $3 \mathrm{~B}$ per enzyme monomer can be reactivated by anti-3B monoclonal antibodies (MAbs) and these recombinant $\beta$ galactosidases could be also efficiently reactivated by sera from infected animals that permitted differentiation between sera from infected animals and those from naïve and conventionally vaccinated pigs. These infection-specific FMDV biosensors can provide an effective and versatile alternative for the serological distinction of FMDV-infected animals [221].

5.11. Nucleic-Acid-Based Diagnostic Methods. FMDV serotypes $\mathrm{A}, \mathrm{O}$, and $\mathrm{C}$ was possible, using cDNA probes from individual serotypes that corresponded to structural protein VP1, where thirteen complementary DNA (cDNA) probes labelled with $32 \mathrm{P}$ were used to detect the presence of footand-mouth disease virus (FMDV) enabled the detection of 1 pg of viral-RNA, or 1 virus copy per cell [222].

A nucleic acid sequence-based amplification (NASBA) assay for the detection of foot-and-mouth disease virus (FMDV) was developed. Two detection methods, NASBAelectrochemiluminescence (NASBA-ECL) and a newly developed NASBA-enzymelinked oligonucleotide capture (NASBA-EOC), were evaluated and compared with other laboratory-based methods, data analysis support the use of NASBA as a rapid and sensitive diagnostic method for the detection and surveillance of FMDV [223].

5.12. Phage Display-Based Diagnosis. Due to the high antigenic variability of FMDV, it is important to undertake mutation analysis under immunological pressure. To study the bovine antibody response at a molecular level, phage display technology was used to produce bovine anti-FMDV Fabs where $\mathrm{CH} 1-\mathrm{VH}$ chains with FMDV specific binding was isolated after selection from a library made from vaccinated cattle [224]. Recently, screening a phage displayed random 12-peptide library, it was found that positive phages displaying the consensus motif ETTXLE ( $\mathrm{X}$ is any amino acid (aa)), which is highly homologous to 6ETTLLE11 at the N-terminus of the VP2 protein (structural protein) of the FMDV, a minimal epitopic region require to bind a monoclonal antibody of serotype independent FMDV (MAb $4 \mathrm{~B} 2$ ) and thus can be used as a universal diagnostic candidate against.

5.13. Pen Side Diagnostic Approach. Routine diagnosis of FMD is made at several laboratories by the combined use of enzyme-linked immunosorbent assay (ELISA), virus isolation techniques, supplemented by reverse transcriptase PCR (RT-PCR), and so forth, which has been already discussed. However, most of these diagnostic methods require the availability of a dedicated laboratory facility, highly trained laboratory personnel, stable reagents, multistep 
sample handling or preparation, and management of the logistical considerations associated with sample collection and transport is also required [122]. A rapid and easy-toperform test, which would allow for on-site diagnosis to be made in the case of a suspected disease outbreak, would circumvent problems associated with the transportation of samples to the laboratory and would be especially useful for a faster diagnosis in areas where the disease is endemic. Availability of "point of care" or "pen-side" diagnostic tests would have the advantage of rapid, user friendly, correct identification of a particular strain and economically feasible diagnosis of FMD in field condition. Development of a rapid chromatographic strip test, lateral flow device (LFD) for penside diagnosis based on a monoclonal antibodies that reacts against FMDV of all seven serotypes [170].

The LFA is an appropriate technology on which to base a rapid assay. The technique permits rapid diagnosis, allowing time for the early implementation of control measures to reduce the possibility of spread of FMD. The LFA has been developed widely to support clinical diagnosis of different diseases [225-227], including FMD [170, 228]. A rapid lateral-flow assay (LFA) based on FMDV antigen detection, which is easy to use and can be utilized on the farm to reduce the time required for transport and laboratory diagnosis. The detection of FMDV antigens by direct application of vesicular fluids and epithelial suspensions from animals of an infected farm may reduce the chances of diagnostic error arising from nonspecific reactions. Oem et al. showed that the diagnostic sensitivity of the LFA for FMDV types $\mathrm{O}, \mathrm{A}, \mathrm{C}$, and Asia 1 was similar, at approximately $87.3 \%$, to that of $87.7 \%$ obtained with antigen enzyme-linked immunosorbent assay (AgELISA). But the specificity of the LFA was $98.8 \%$, compared to $100 \%$ for the AgELISA [122]. Recently a lateral flow device (LFD) for the detection of footand-mouth disease virus (FMDV) of the SAT 2 serotype was developed using a monoclonal antibody (Mab 2H6) for providing rapid and objective support to veterinarians in their clinical judgment of the disease and for specific confirmation of a FMDV type SAT 2 infection [229].

Again a simple, rapid, colloidal gold-based immuno chromatographic strip tests were developed for easy clinical testing of serotype A of FMDV in field sites was developed with sensitivity and specificity $88.7 \%$ and $98.7 \%$, respectively [230]. Such pen-side diagnosis would have particular benefits in FMD emergencies, relevance to FMD control programmes which operate in endemic regions of the world such as South East Asia and for increasing disease awareness in other areas where efforts to control disease may be difficult [170]. In each circumstance the availability of a pen-side device for diagnosis would reduce the necessity for sending routine diagnostic samples to an FMD laboratory and thereby reduce the delay in diagnosis, which can in some areas be considerable.

An alternative molecular technique called Loop Mediated Isothermal Amplification (LAMP) was developed for detection of viruses, where target DNA or RNA specifically amplify using four specific primers under isothermal conditions $[231,232]$. A new version LAMP called Reverse Transcription Loop Mediated Isothermal Amplification (RT-LAMP) was developed for rapid, specific and sensitive detection of viruses including FMDV in laboratory and in field condition $[233,234]$.

\section{Conclusion}

Foot-and-mouth disease virus (FMDV) is an important veterinary pathogen which can cause widespread epidemics. Many works have been carried out to develop and validate diagnostic tests in regard to the FMD. Conventional techniques to detect FMDV infection are either not precisely specific or lack an optimum degree of sensitivity which cannot be overlooked when screening of a herd is concerned. With the critical need for improved diagnostic tests to detect viral infection, effort need to be concentrated on the development of simple, rapid, noninvasive tests that can be performed without expensive laboratory equipment. In this context although various molecular tools are very promising but to make it a successful tool search for more rapid and accurate tests as well as an earlier detection system in preclinical state are needed for the hour.

\section{References}

[1] J. B. Brooksby, "Portraits of viruses: foot-and-mouth disease virus," Intervirology, vol. 18, no. 1-2, pp. 1-23, 1982.

[2] H. Fracastorius, De Contagion et Contagiosus Morbis et Curatione, Book 1, chapter 12, Venecia, 1546.

[3] F. Loeffler and P. Frosch, "Summarischer bericht uber die ergebnisse der untersuchungen zur erforschung der maulund klauenseuche," Zentbl Bakteriol Parasitenkd Infektionskr Hyg Abt I, vol. 22, pp. 257-259, 1897.

[4] E. Domingo, M. G. Mateu, M. A. Martínez, J. Dopazo, A. Moya, and F. Sobrino, "Genetic variability and antigenic diversity of foot-and-mouth disease virus," in Applied Virology Research, E. Kurstak, R. G. Marusk, S. A. Murphy, and M. H. V. Van Regenmortel, Eds., vol. 2, pp. 233-266, 1990.

[5] E. L. Woodbury, "A review of the possible mechanisms for the persistence of foot-and-mouth disease virus," Epidemiology and Infection, vol. 114, no. 1, pp. 1-13, 1995.

[6] P. K. Sharma and S. K. Das, "Occurrence of foot-and-mouth disease and distribution of virus type in the hill states of North Eastern region of India," Indian Journal of Animal Sciences, vol. 4, pp. 117-118, 1984.

[7] R. P. Tamilselvan, A. De Sanyal, and B. Pattnaik, Genetic transitions of Indian serotype O Foot and Mouth Disease Virus isolates responsible for field outbreaks during 20012009: a brief note: OIE/FAO Reference laboratories network meeting: New Delhi, India, pp. 11-13, November, 2009.

[8] V. R. Racaniello, "Picornaviridae: the viruses and their replication," in Fields Virology, pp. 685-722, Lippincott Williams \& Wilkins, Philadelphia, Pa, USA, 3rd edition, 2001.

[9] H. G. Pereira, "Subtyping of foot-and-mouth disease virus," Developments in Biological Standardization, vol. 35, pp. 167174, 1977.

[10] H. Vallee and H. Carre, "Sur la pluralite du virus aphteux," Comptes Rendus de l'Académie des Sciences, vol. 174, p. 1498, 1922.

[11] O. Waldmann and K. Trautwein, "Experimentelle untersuchungen ueber die pluralitet des maulund klauenseuche virus," Berliner und Münchener tierärztliche Wochenschrift, vol. 91, pp. 3-7, 2003. 
[12] J. B. Brooksyby and J. Rogers, "Methods used in typing the virus of foot-andmouth disease at Pirbright, 1950-55," in Method of Typing and Cultivation of Foot and Mouth Disease Virus, pp. 31-34, OEEC, Paris, France, 1957.

[13] H. L. Bachrach, "Foot-and-mouth disease," Annual Review of Microbiology, vol. 22, pp. 201-244, 1968.

[14] M. D. Ryan, G. J. Belsham, and A. M. Q. King, "Specificity of enzyme-substrate interactions in foot-and-mouth disease virus polyprotein processing," Virology, vol. 173, no. 1, pp. 35-45, 1989.

[15] F. A. Murphy, E. P. J. Gibbs, M. C. Horzinek, and M. J. Studdert, Picornaviridae. Veterinary Virology, Academic Press, London, UK, 3rd edition, 1999.

[16] R. Acharya, E. Fry, D. Stuart, G. Fox, D. Rowlands, and F. Brown, "The three-dimensional structure of foot-andmouth disease virus at $2.9 \mathrm{~A}^{\circ}$ resolution," Nature, vol. 337, no. 6209, pp. 709-716, 1989.

[17] M. G. Mateu, "Antibody recognition of picornaviruses and escape from neutralization: a structural view," Virus Research, vol. 38, no. 1, pp. 1-24, 1995.

[18] D. Logan, R. Abu-Ghazaleh, W. Blakemore et al., "Structure of a major immunogenic site on foot-and-mouth disease virus," Nature, vol. 362, no. 6420, pp. 566-568, 1993.

[19] J. L. Bittle, R. A. Houghten, and H. Alexander, "Protection against foot-and-mouth disease by immunization with a chemically synthesized peptide predicted from the viral nucleotide sequence," Nature, vol. 298, no. 5869, pp. 30-33, 1982.

[20] S. Lea, J. Hernández, W. Blakemore et al., "The structure and antigenicity of a type C foot-and-mouth disease virus," Structure, vol. 2, no. 2, pp. 123-139, 1994.

[21] D. J. Morrell, E. J. C. Mellor, D. J. Rowlands, and F. Brown, "Surface structure and RNA-protein interactions of footand-mouth disease virus," Journal of General Virology, vol. 68, no. 6, pp. 1649-1658, 1987.

[22] D. W. Bruner and J. H. Gillespie, "The family Picornaviridae," in Hagan's Infectious Disease of Domestic Animals, pp. 12071028, 6th edition, 1973.

[23] E. Traub and H. Mohalman, "Foot-and- mouth disease typing with complement fixation test first communication. Experiment with serum and antigen of guinea pigs," Zentbl Bakteriol Parasitenkd Infektionskr Hyg Abt I Orig, vol. 150, pp. 289-300, 1943.

[24] M. M. Rweyemamu, J. C. Booth, M. Head, and T. W. F. Pay, "Microneutralization tests for serological typing and subtyping of foot-and-mouth disease virus strains," Journal of Hygiene, vol. 81, no. 1, pp. 107-123, 1978.

[25] P. Have, J. C. Lei, and K. Schjerning-Thiesen, "An engyme linked immunosorbent assay (ELISA) for the primary diagnosis of foot-and-mouth disease: characterization and comparison with complement fixation," Acta Veterinaria Scandinavica. Supplementum, vol. 25, no. 2, pp. 280-296, 1984.

[26] N. P. Ferris and M. Dawson, "Routine application of enzyme-linked immunosorbent assay in comparison with complement fixation for the diagnosis of foot-and-mouth and swine vesicular diseases," Veterinary Microbiology, vol. 16, no. 3, pp. 201-209, 1988.

[27] W. Vangrysperre and K. De Clercq, "Rapid and sensitive polymerase chain reaction based detection and typing of foot-and-mouth disease virus in clinical samples and cell culture isolates, combined with a simultaneous differentiation with other genomically and/or symptomatically related viruses," Archives of Virology, vol. 141, no. 2, pp. 331-344, 1996.
[28] M. S. Rossi, A. M. Sadir, A. A. Schudel, and E. L. Palma, "Detection of Foot-and-Mouth disease virus with DNA probes in bovine esophageal-pharingeal fluids," Archives of Virology, vol. 99, no. 1-2, pp. 67-74, 1988.

[29] R. F. Meyer, C. C. Brown, C. House, J. A. House, and T. W. Molitor, "Rapid and sensitive detection of foot-and-mouth disease virus in tissues by enzymatic RNA amplification of the polymerase gene," Journal of Virological Methods, vol. 34, no. 2, pp. 161-172, 1991.

[30] O. Laor, H. Torgersen, H. Yadin, and Y. Becker, "Detection of FMDV RNA amplified by the polymerase chain reaction (PCR)," Journal of Virological Methods, vol. 36, no. 3, pp. 197207, 1992.

[31] C. M. F. Amaral-Doel, N. E. Owen, N. P. Ferris, R. P. Kitching, and T. R. Doel, "Detection of foot-and-mouth disease viral sequences in clinical specimens and ethyleneimineinactivated preparations by the polymerase chain reaction," Vaccine, vol. 11, no. 4, pp. 415-421, 1993.

[32] M. C. Hofner, W. C. Carpenter, and A. I. Donaldson, "Detection of foot-and-mouth disease virus RNA in clinical samples and cell culture isolates by amplification of the capsid coding region," Journal of Virological Methods, vol. 42, no. 1, pp. 53-62, 1993.

[33] A. Rodriguez, J. I. Nunez, G. Nolasco, F. Ponz, F. Sobrino, and C. De Blas, "Direct PCR detection of foot-and-mouth disease virus,” Journal of Virological Methods, vol. 47, pp. 345-349, 1994.

[34] O. Marquardt, O.C. Straub, R. Ahl, and B. Hass, "Detection of foot-and-mouth disease virus in nasal swabs of asymptomatic cattle by RT-PCR within 24 hours," Journal of Virological Methods, vol. 53, no. 2-3, pp. 255-261, 1995.

[35] S. M. Reid, M. A. Forsyth, G. H. Hutchings, and N. P. Ferris, "Comparison of reverse transcription polymerase chain reaction, enzyme linked immunosorbent assay and virus isolation for the routine diagnosis of foot-and-mouth disease," Journal of Virological Methods, vol. 70, no. 2, pp. 213-217, 1998.

[36] M. Callens and K. De Clercq, "Differentiation of the seven serotypes of foot-and-mouth disease virus by reverse transcriptase polymerase chain reaction," Journal of Virological Methods, vol. 67, no. 1, pp. 35-44, 1997.

[37] P. Giridharan, D. Hemadri, C. Tosh, A. Sanyal, and S. K. Bandyopadhyay, "Development and evaluation of a multiplex PCR for differentiation of foot-and-mouth disease virus strains native to India," Journal of Virological Methods, vol. 126, no. 1-2, pp. 1-11, 2005.

[38] J. I. Núñez, E. Blanco, T. Hernández et al., "A RT-PCR assay for the differential diagnosis of vesicular viral diseases of swine," Journal of Virological Methods, vol. 72, no. 2, pp. 227235, 1998.

[39] S. M. Reid, N. P. Ferris, G. H. Hutchings, Z. Zhang, G. J. Belsham, and S. Alexandersen, "Detection of all seven serotypes of foot-and-mouth disease virus by real-time, fluorogenic reverse transcription polymerase chain reaction assay," Journal of Virological Methods, vol. 105, no. 1, pp. 6780, 2002.

[40] F. Loeffler and P. Frosch, "Berichte der kommission zur erforschung der maulund klauenseuche bei dem Institut für Infectrionskrankheiten in Berlin," Zentbl Bakteriol Parasitenkd Infektionskr Hyg Abt I Orig, vol. 23, pp. 371-391, 1898.

[41] W. M. Lee, S. S. Monroe, and R. R. Rueckert, "Role of maturation cleavage in infectivity of picornaviruses: activation of an infectosome," Journal of Virology, vol. 67, no. 4, pp. 2110 2122, 1993. 
[42] T. Jackson, A. M. Q. King, D. I. Stuart, and E. Fry, "Structure and receptor binding," Virus Research, vol. 91, no. 1, pp. 3346, 2003.

[43] E. Domingo, C. Escarmís, M. A. Martinez, E. MartinezSalas, and M. G. Mateu, "Foot-and-mouth disease virus populations are quasispecies," Current Topics in Microbiology and Immunology, vol. 176, pp. 33-47, 1992.

[44] G. J. Belsham, C. C. Abrams, A. M. Q. King, J. Roosien, and J. M. Vlak, "Myristoylation of foot-and-mouth disease virus capsid protein precursors is independent of other viral proteins and occurs in both mammalian and insect cells," Journal of General Virology, vol. 72, no. 3, pp. 747-751, 1991.

[45] T. Jackson, A. P. Mould, D. Sheppard, and A. M. Q. King, "Integrin $\alpha \mathrm{v} \beta 1$ is a receptor for Foot-and-mouth disease virus," Journal of Virology, vol. 76, no. 3, pp. 935-941, 2002.

[46] D. M. Belnap, B. M. McDermott, D. J. Filman et al., "Three-dimensional structure of poliovirus receptor bound to poliovirus," Proceedings of the National Academy of Sciences of the United States of America, vol. 97, no. 1, pp. 73-78, 2000.

[47] J. Laporte and G. Lenoir, "Structural proteins of foot and mouth disease virus," Journal of General Virology, vol. 20, no. 2, pp. 161-168, 1973.

[48] D. Cavanagh, D. V. Sangar, D. J. Rowlands, and F. Brown, "Immunogenic and cell attachment sites of FMDV: further evidence for their location in a single capsid polypeptide," Journal of General Virology, vol. 35, no. 1, pp. 149-158, 1977.

[49] K. Strohmaier, R. Franze, and K. H. Adam, "Location and characterization of the antigenic portion of the FMDV immunizing protein," Journal of General Virology, vol. 59, no. 2, pp. 295-306, 1982.

[50] T. Bunch, E. Rieder, and P. Mason, "Sequence of the S fragment of foot-and-mouth disease virus type A," Virus Genes, vol. 8, no. 2, pp. 173-175, 1994.

[51] M. P. Costa Giomi, I. E. Bergmann, and E. A. Scodeller, "Heterogeneity of the polyribocytidylic acid tract in aphthovirus: biochemical and biological studies of viruses carrying polyribocytidylic acid tracts of different lengths," Journal of Virology, vol. 51, no. 3, pp. 799-805, 1984.

[52] T. J. R. Harris and F. Brown, "Biochemical analysis of a virulent and an avirulent strain of foot and mouth disease virus," Journal of General Virology, vol. 34, no. 1, pp. 87-105, 1977.

[53] M. J. Grubman and B. Baxt, "Foot-and-Mouth Disease," Clinical Microbiology Reviews, vol. 17, no. 2, pp. 465-493, 2004.

[54] P. W. Mason, S. V. Bezborodova, and T. M. Henry, "Identification and characterization of a cis-acting replication element (cre) adjacent to the internal ribosome entry site of foot-and-mouth disease virus," Journal of Virology, vol. 76, no. 19, pp. 9686-9694, 2002.

[55] S. K. Jang, H. G. Krausslich, M. J. H. Nicklin, G. M. Duke, A. C. Palmenberg, and E. Wimmer, "A segment of the 5' nontranslated region of encephalomyocarditis virus RNA directs internal entry of ribosomes during in vitro translation," Journal of Virology, vol. 62, no. 8, pp. 2636-2643, 1988.

[56] E. V. Pilipenko, A. P. Gmyl, S. V. Maslova, Y. V. Svitkin, A. N. Sinyakov, and V. I. Agol, "Prokaryotic-like cis elements in the cap-independent internal initiation of translation on picornavirus RNA," Cell, vol. 68, no. 1, pp. 119-131, 1992.

[57] K. Dorsch Hasler, Y. Yogo, and E. Wimmer, "Replication of picornaviruses. I. Evidence from in vitro RNA synthesis that poly(A) of the poliovirus genome is genetically coded," Journal of Virology, vol. 16, no. 6, pp. 1512-1527, 1975.
[58] E. V. Pilipenko, K. V. Poperechny, S. V. Maslova, W. J. G. Melchers, H. J. Bruins Slot, and V. I. Agol, "Cis-element, oriR, involved in the initiation of (-) strand poliovirus RNA: a quasi-globular multi-domain RNA structure maintained by tertiary ('kissing') interactions," The EMBO Journal, vol. 15, no. 19, pp. 5428-5436, 1996.

[59] S. López de Quinto, M. Sáiz, D. de La Morena, F. Sobrino, and E. Martínez-Salas, "IRES-driven translation is stimulated separately by the FMDV $3^{\prime}$-NCR and poly(A) sequences," Nucleic Acids Research, vol. 30, no. 20, pp. 4398-4405, 2002.

[60] J. Herold and R. Andino, "Poliovirus RNA replication requires genome circularization through a protein-protein bridge," Molecular Cell, vol. 7, no. 3, pp. 581-591, 2001.

[61] G. J. Belsham, "Distinctive features of foot-and-mouth disease virus, a member of the picornavirus family; aspects of virus protein synthesis, protein processing and structure," Progress in Biophysics and Molecular Biology, vol. 60, no. 3, pp. 241-260, 1993.

[62] M. D. Ryan, A. M. Q. King, and G. P. Thomas, "Cleavage of foot-and-mouth disease virus polyprotein is mediated by residues located within a 19 amino acid sequence," Journal of General Virology, vol. 72, no. 11, pp. 2727-2732, 1991.

[63] J. F. E. Newman, P. G. Piatti, M. D. Ryan, and F. Brown, "Function of minor polypeptides in foot-and-mouth disease virus and poliovirus," Trends in Microbiology, vol. 2, no. 12, pp. 494-496, 1994.

[64] A. V. E. Capozzo, D. J. Burke, J. W. Fox, I. E. Bergmann, J. L. La Torre, and P. R. Grigera, "Expression of foot and mouth disease virus non-structural polypeptide $3 \mathrm{ABC}$ induces histone H3 cleavage in BHK21 cells," Virus Research, vol. 90, no. 1-2, pp. 91-99, 2002.

[65] M. L. L. Donnelly, D. Gani, M. Flint, S. Monaghan, and M. D. Ryan, "The cleavage activities of aphthovirus and cardiovirus 2A proteins," Journal of General Virology, vol. 78, no. 1, pp. 13-21, 1997.

[66] R. F. Sellers, "Quantitative aspects of the spread of foot and mouth disease," Veterinarian, vol. 41, pp. 431-439, 1971.

[67] A. I. Donaldson, C. F. Gibson, R. Oliver, C. Hamblin, and R. P. Kitching, "Infection of cattle by airborne foot-and-mouth disease virus: minimal doses with O1 and SAT2 strains," Research in Veterinary Science, vol. 43, no. 3, pp. 339-346, 1987.

[68] H. Nishiura and R. Omori, "An epidemiological analysis of the foot-and-mouth disease epidemic in Miyazaki, Japan, 2010," Transboundary and Emerging Diseases, vol. 57, no. 6, pp. 396-403, 2010.

[69] N. M. Ferguson, C. A. Donnelly, and R. M. Anderson, "The foot-and-mouth epidemic in Great Britain: pattern of spread and impact of interventions," Science, vol. 292, no. 5519, pp. 1155-1160, 2001.

[70] F. Sobrino and E. Domingo, "Foot-and-mouth disease in Europe," EMBO Reports, vol. 2, no. 6, pp. 459-461, 2001.

[71] S. Prasad, "Distribution of different types of foot-andmouth disease virus in North-West region of India," Haryana Veterinarian, vol. 10, pp. 26-29, 1971.

[72] S. C. Tewari, I. P. Singh, R. V. K. Sharma, R. Pandey, and S. Prasad, "A note on the incidence and distribution of footand-mouth disease virus types in north-west India," Indian Journal of Animal Sciences, vol. 45, pp. 159-160, 1975.

[73] S. Prasad, M. C. Goel, V. K. Sharma et al., "A note on the incidence and distribution of foot-and-mouth disease virus types in North-West region of India," Indian Journal of Animal Sciences, vol. 48, pp. 627-629, 1978. 
[74] K. L. Ramakant Ahuja, S. Prasad, S. C. Tewari, and V. K. Sharma, "Distribution of foot-and-mouth disease virus in North-West India," Haryana Veterinarian, vol. 19, pp. 144146, 1980.

[75] A. Kumar, S. Prasad, K. L. Ahuja, S. C. Tewari, S. C. Dogra, and D. N. Garg, "Distribution pattern of foot-and-mouth disease virus types in North-West India (1979-81)," Haryana Veterinarian, vol. 22, pp. 28-30, 1983.

[76] K.L. Ahuja, A. Kumar, S. Prasad, and R. Sharma, "Incidence and distribution of foot-and-mouth disease virus types in North-West India (1982-84)," Indian Journal of Animal Sciences, vol. 56, pp. 503-505, 1986.

[77] K.L. Ahuja, A. Kumar, and S. Prasad, "Incidence and distribution of foot-andmouth disease virus types in NorthWest India (1991-93)," Indian Journal of Virology, vol. 12, pp. 125-127, 1996.

[78] P. K. Dutta, G. Sharma, and S. K. Das, "Occurrence of footand-mouth disease and distribution of virus type in the hill states of North Eastern region of India," Indian Journal of Animal Sciences, vol. 4, pp. 117-118, 1984.

[79] D. K. Sarma, P. K. Dutta, and A. K. Harzarika, "Foot-andmouth disease in North Eastern India during 1991," Virus Information Exchange Newsletter for South East Asia and the Western Pacific, vol. 9, pp. 63-64, 1992.

[80] B. U. Rao, "Development, production and application of vaccines in FMD control in India," in Progress in Vaccinology, G. P. Talwar, Ed., vol. 2, pp. 283-290, Springer, New York, NY, USA, 1989.

[81] N. Mishra, S. Mishra, and P. S. K. Bhagwan, "Vaccines for small ruminants-need and development strategies," Livestock International, vol. 2, no. 8, pp. 9-11, 1998.

[82] A. K. Mukhopadhyay, Distribution of FMD Virus Types and Subtypes in India. Summer Institute on Recent Advances in Diagnosis and Control of FMD, I. V. R. I., Bangalore, India, 1992.

[83] Anonymous. Report, Institute of Rural Management, Anand, 1991.

[84] S. Pyakural, U. Singh, and N. B. Singh, "An outbreak of footand-mouth disease in Indian elephants (Elephas maximas)," Veterinary Record, vol. 99, no. 2, pp. 28-29, 1976.

[85] P. K. Dutta, P. N. Mahanta, and A. K. Chakraborty, "FMD in mithun," Veterinary Record, pp. 113-114, 1979.

[86] N. D. Verma and D. K. Sarma, "Note on foot-and-mouth disease in mithun in arunachal pradesh," Indian Journal of Virology, vol. 13, no. 1, pp. 75-76, 1997.

[87] N. N. Barman, D. K. Sarma, S. Das, and G. P. Patgiri, "Footand-mouth disease in wild and semi-domesticated animals of the northeastern states of India," Indian Journal of Animal Sciences, vol. 69, no. 10, pp. 781-783, 1999.

[88] W. Vosloo, K. Boshoff, R. Dwarka, and A. Bastos, "The possible role that buffalo played in the recent outbreaks of foot-and-mouth disease in South Africa," Annals of the New York Academy of Sciences, vol. 969, pp. 187-190, 2002.

[89] P. Sutmoller, "Vesicular diseases," in Foreign Animal Diseases, pp. 368-382, Foreign Animal Diseases of the United States Animal Health Association, Richmond, Va, USA, 1992.

[90] R. Burrows, J. A. Mann, and A. J.M. Garland, "The pathogenesis of natural and simulated natural foot-and-mouth disease infection in cattle," Journal of Comparative Pathology, vol. 91, no. 4, pp. 599-609, 1981.

[91] J. S. Salt, "The carrier state in foot and mouth disease-an immunological review," British Veterinary Journal, vol. 149, no. 3, pp. 207-223, 1993.
[92] O. M. Radostits, D. C. Blood, and C. C. Gay, "Veterinary Medicine," in Educational Low-Priced Scheme, pp. 965-973, Balliére Tindall, London, UK, 8th edition, 1994.

[93] A. Buxton and G. Fraser, Animal Microbiology, vol. 2, Blackwell Scientific Publications, Oxford, UK, 1977.

[94] N. J. Knowles, A. R. Samuel, P. R. Davies, R. P. Kitching, and A. I. Donaldson, "Outbreak of foot-and-mouth disease virus serotype $\mathrm{O}$ in the UK caused by a pandemic strain," Veterinary Record, vol. 148, no. 9, pp. 258-259, 2001.

[95] W. Vosloo, A. D. Bastos, E. Kirkbride et al., "Persistent infection of African buffalo (Syncerus caffer) with SATtype foot-and-mouth disease viruses: rate of fixation of mutations, antigenic change and interspecies transmission," Journal of General Virology, vol. 77, no. 7, pp. 1457-1467, 1996.

[96] M. Rémond, C. Kaiser, and F. Lebreton, "Diagnosis and screening of foot-and-mouth disease," Comparative Immunology, Microbiology and Infectious Diseases, vol. 25, no. 5-6, pp. 309-320, 2002.

[97] O. Waldmann and J. Pape, "Die kuenstilche uebertragung der maulund klauenseuche auf das meerschweinchen," Berliner und Münchener tierärztliche Wochenschrift, vol. 36, pp. 519520, 1920.

[98] F. Brown, "The history of research in foot-and-mouth disease," Virus Research, vol. 91, no. 1, pp. 3-7, 2003.

[99] S. P. Bedson, H. B. Maitland, and Y. M. Burbury, Footand-Mouth Disease Research Committee, 2nd report, HMSO, London, UK, 1927.

[100] M. M. Rweyemamu, "Developments in the biochemical and immunoassays assessment of foot-and-mouth antigen," in Proceedings of the Internationals Conference on the Impact of Viral Disease on the Development of Latin American Countries and Caribbean Region, pp. 78-79, Rio de Janeiro, Brazil, 1982.

[101] N. Longjam, A. K. Sarmah, R. Deb, B. Mathapati, V. K. Saxena, and T. Tayo, "Detection of foot and mouth disease virus serotype $\mathrm{O}$ by sandwich ELISA, viral isolation and multiplex PCR," Online Journal of Veterinary Research, vol. 15, no. 1, pp. 76-92, 2011.

[102] N. P. Ferris, A. I. Donaldson, I. T. R. Barnett, and R. W. Osborne, "Inactivation, purification and stability of $146 \mathrm{~S}$ antigens of foot-and-mouth disease virus for use as reagent in the complement fixation test," Revue Scientifique et Technique (International Office of Epizootics), vol. 3, pp. 339-350, 1984.

[103] Y. A. Ivanov and P. Tekerlekov, "Typing Aphthovirus by the micro-complement fixation test," Veterinarya Sbrika, vol. 87, pp. 18-21, 1989.

[104] J. H. Darbyshire, R. S. Hedger, and E. M. Arrowsmith, "Comparative complement-fixation studies with subtype strains of foot-and-mouth disease virus," Journal of Hygiene, vol. 70, no. 1, pp. 171-180, 1972.

[105] Anonymous, Annual report of the Indian veterinary research institute, Mukteswar, (1964-1965).

[106] A. Rai, "Subtyping of foot-and-mouth disease isolate types $\mathrm{O}$ and Asia 1 recovered from field outbreaks in India," Indian Journal of Animal Sciences, vol. 50, pp. 164-168, 1980.

[107] A. Rai, "A comparative study of the micro-complement fixation and micro neutralization tests in the subtyping of foot and mouth disease virus," Indian Journal of Animal Sciences, vol. 50, pp. 961-965, 1980.

[108] R. F. Sellers, "Growth and titration of the viruses of foot-andmouth disease and vesicular stomatitis in kidney monolayer tissue cultures," Nature, vol. 176, pp. 121-124, 1955. 
[109] W. A. Snowdon, "Growth of foot-and-mouth disease virus in monolayer cultures of calf thyroid cells," Nature, vol. 210, no. 5040, pp. 1079-1080, 1966.

[110] C. House and J. A. House, "Evaluation of techniques to demonstrate foot-and-mouth disease virus in bovine tongue epithelium: comparison of the sensitivity of cattle, mice, primary cell cultures, cryopreserved cell cultures and established cell lines," Veterinary Microbiology, vol. 20, no. 2, pp. 99-109, 1989.

[111] H. L. Bachrach, W. R. Hess, and J. J. Callis, "Foot-andmouth disease virus: its growth and cytopathogenicity in tissue culture," Science, vol. 122, pp. 1269-1270, 1955.

[112] S. P. Nair, "Studies on the susceptibility and growth pattern of foot-and-mouth disease virus vaccine strains in two pig kidney cell lines," Indian Journal of Comparative Microbiology, Immunology and Infectious Diseases, vol. 8, no. 2, pp. 76-81, 1987.

[113] S. K. Dinka, L. M. Swaney, and J. W. McVicar, "Selection of a stable clone of the MVPK 1 fetal porcine kidney cell for assays of foot and mouth disease virus," Canadian Journal of Microbiology, vol. 23, no. 3, pp. 295-299, 1977.

[114] J. A. House, C. House, and M. E. Llewellyn, "Characteristics of the porcine kidney cell line IB-RS-2 clone D10 (IB-RS-2 D10) which is free of hog cholera virus," In Vitro Cellular \& Developmental Biology, vol. 24, no. 7, pp. 677-682, 1988.

[115] J. B. Clarke and R. E. Spier, "Variation in the susceptibility of BHK populations and cloned cell lines to three strains of foot-and-mouth disease virus," Archives of Virology, vol. 63, no. 1, pp. 1-9, 1980.

[116] S. Revenson and M. Segura, "Multiplication of foot-andmouth disease virus in roller tube culture BHK-21 cells of hamster kidney," Revenue Canada Investigation, vol. 18, pp. 293-299, 1963.

[117] H. C. Girard, Evolution of BHK Cells, FAO, Brescia, Italy, 1975.

[118] J. B. Clarke and R. E. Spier, "Studies on the susceptibility to foot-and-mouth disease virus of BHK cell cultures derived from various sources," Developments in Biological Standardization, vol. 35, pp. 61-66, 1977.

[119] N. Mishra, D. V. Rai, and B. Pattnaik, "Strain differentiation of foot-and-mouth disease virus type 'Asia1'”' Indian Journal of Animal Sciences, vol. 65, pp. 368-375, 1995.

[120] A. C. Goel and A. Rai, "Growth curve, plaque assay and inactivation studies of FMD virus subtypes O5, O1 and O6 of Indian origin," Indian Journal of Comparative Microbiology, Immunology and Infectious Diseases, vol. 6, no. 1, pp. 16-28, 1985.

[121] S. J. Barteling, F. Wagenaar, and A. L.J. Gielkens, "The positively charged structural virus protein (VP1) of footand-mouth disease virus (type O1) contains a highly basic part which may be involved in early virus-cell interaction," Journal of General Virology, vol. 62, no. 2, pp. 357-361, 1982.

[122] K. U. O. Jae, N. P. Ferris, K. N. Lee, Y. I. S. Joo, B. H. Hyun, and J. H. Park, "Simple and rapid lateral-flow assay for the detection of foot-and-mouth disease virus," Clinical and Vaccine Immunology, vol. 16, no. 11, pp. 1660-1664, 2009.

[123] A. J. Forman, "A comparison of some immunological methods for the differentiation of strains of foot and mouth disease virus," Journal of Hygiene, vol. 74, no. 2, pp. 215-225, 1975.

[124] M. M. Rweyemamu, "Antigenic variation in foot-and-mouth disease: studies based on the virus neutralization reaction," Journal of Biological Standardization, vol. 12, no. 3, pp. 323337, 1984.
[125] E. M. E. Abu Elzein and J. R. Crowther, "Enzyme-labelled immunosorbent assay techniques in foot-and-mouth disease virus research," Journal of Hygiene, vol. 80, no. 3, pp. 391-399, 1978.

[126] J. R. Crowther and E. M. E. Abu Elzein, "Application of the enzyme linked immunosorbent assay to the detection and identification of foot-and-mouth disease viruses," Journal of Hygiene, vol. 83, no. 3, pp. 513-519, 1979.

[127] E. J. Ouldridge, P. Barnett, and M. M. Rweyemamu, "The relative efficiency of two ELISA techniques for the tritration of FMD antigen," Current Topics in Veterinary Medicine and Animal Science, vol. 22, pp. 142-151, 1982.

[128] E. M. E. Abu Elzein and J. R. Crowther, "The specific detection of foot-and-mouth disease virus whole particle antigen (140S) by enzyme labelled immunosorbent assay," Journal of Hygiene, vol. 83, no. 1, pp. 127-134, 1979.

[129] A. Rai and D. K. Lahiri, "A micro-enzyme-labelled immunosorbent assay (MICROELISA) for the detection of foot-and-mouth disease virus antigen and antibody," Acta Virologica, vol. 25, no. 1, pp. 49-52, 1981.

[130] C. Hamblin, R. M. Armstrong, and R. S. Hedger, "A rapid enzyme-linked immunosorbent assay for the detection of foot-and-mouth disease virus in epithelial tissues," Veterinary Microbiology, vol. 9, no. 5, pp. 435-443, 1984.

[131] E. J. Ouldridge, P. V. Barnett, J. Hingley, and M. M. Rweyemamu, "The differentiation of foot and mouth disease virus strains using an indirect sandwich enzyme-linked immunosorbent assay saturation model," Journal of Biological Standardization, vol. 12, no. 4, pp. 367-377, 1984.

[132] P. L. Roeder and P. M. Le Blanc Smith, "Detection and typing of foot-and-mouth disease virus by enzyme-linked immunosorbent assay: a sensitive, rapid and reliable technique for primary diagnosis," Research in Veterinary Science, vol. 43, no. 2, pp. 225-232, 1987.

[133] B. Pattnaik and R. Venkataramanan, "Indirect enzyme linked immunosorbent assay for the detection of FMDV antigen," Indian Journal of Animal Sciences, vol. 59, pp. 317-322, 1989.

[134] B. Pattnaik and R. Venkataramanan, "A sandwich enzyme linked immunosorbent assay for subtype analysis of footand-mouth disease virus isolate," Indian Journal of Animal Sciences, vol. 59, pp. 1363-1368, 1989.

[135] R. P. Kitching, R. Rendle, and N. P. Ferris, "Rapid correlation between field isolates and vaccine strains of foot-and-mouth disease virus," Vaccine, vol. 6, no. 5, pp. 403-408, 1988.

[136] B. Pattnaik, D. V. Rai, and R. Venkataramanan, "Specificity of foot-and-mouth disease virus antigen and antibody reaction in liquid phase ELISA," Indian Journal of Animal Sciences, vol. 61, pp. 235-240, 1991.

[137] R. A. Lunt, W. Linchongsubongkoch, and L. J. Gleeson, "A modified liquid phase (LP) blocking ELISA used to assess type $\mathrm{O}$ foot-and-mouth disease virus antigenic variation in Thailand," Veterinary Microbiology, vol. 42, no. 1, pp. 79-90, 1994.

[138] G. A. Paiba, J. Anderson, D. J. Paton et al., "Validation of a foot-and-mouth disease antibody screening solid-phase competition ELISA (SPCE)," Journal of Virological Methods, vol. 115, no. 2, pp. 145-158, 2004.

[139] S. Bhattacharya, B. Pattnaik, and R. Venkataramanan, "Development and application of a sandwich enzyme-linked immunosorbent assay (ELISA) for type identification of foot-and-mouth-disease (FMD) virus in direct field materials," Indian Journal of Animal Sciences, vol. 66, no. 12, pp. 1201-1209, 1996. 
[140] M. J. Grubman and B. Baxt, "Foot-and-mouth disease," Clinical Microbiology Reviews, vol. 17, no. 2, pp. 465-493, 2004.

[141] R. K. Saiki, S. J. Scharf, A. F. Faloona, K. B. Mullis, H. Erlich, and N. Arnheim, "Enzymatic amplification of $\beta$ goblin genomic sequence and restriction site analysis for the diagnosis of sickle cell anemia," Science, vol. 230, pp. 1350$1354,1985$.

[142] K. B. Mullis and F. A. Faloona, "Specific synthesis of DNA in vitro via a polymerase-catalyzed chain reaction," Methods in Enzymology, vol. 155, pp. 335-350, 1987.

[143] M. Callens, K. De Clercq, M. Gruia, and M. Danes, "Detection of foot-and-mouth disease by reverse transcription polymerase chain reaction and virus isolation in contact sheep without clinical signs of foot-and-mouth disease," Veterinary Quarterly, vol. 20, no. 2, pp. S37-S40, 1998.

[144] M. Callens and K. De Clercq, "Highly sensitive detection of swine vesicular disease virus based on a single tube RTPCR system and DIG-ELISA detection," Journal of Virological Methods, vol. 77, no. 1, pp. 87-99, 1999.

[145] S. Alexandersen, M. A. Forsyth, S. M. Reid, and G. J. Belsham, "Development of reverse transcription-PCR (oligonucleotide probing) enzyme-linked immunosorbent assays for diagnosis and preliminary typing of foot-and-mouth disease: a new system using simple and aqueous-phase hybridization," Journal of Clinical Microbiology, vol. 38, no. 12, pp. 46044613, 2000.

[146] P. Moonen, J. Boonstra, R. Hakze-van der Honing, C. Boonstra-Leendertse, L. Jacobs, and A. Dekker, "Validation of a LightCycler-based reverse transcription polymerase chain reaction for the detection of foot-and-mouth disease virus," Journal of Virological Methods, vol. 113, no. 1, pp. 3541, 2003.

[147] A. Moss and B. Haas, "Comparison of the plaque test and reverse transcription nested PCR for the detection of FMDV in nasal swabs and probang samples," Journal of Virological Methods, vol. 80, no. 1, pp. 59-67, 1999.

[148] S. M. Reid, G. H. Hutchings, N. P. Ferris, and K. De Clercq, "Diagnosis of footand-mouth disease by RTPCR: evaluation of primers for serotypic characterisation of viral RNA in clinical samples," Journal of Virological Methods, vol. 83, pp. 113-123, 1999.

[149] S. M. Reid, N. P. Ferris, G. H. Hutchings, A. R. Samuel, and N. J. Knowles, "Primary diagnosis of foot-and-mouth disease by reverse transcription polymerase chain reaction," Journal of Virological Methods, vol. 89, no. 1-2, pp. 167-176, 2000.

[150] H. F. Bao, D. Li, J. H. Guo et al., "A highly sensitive and specific multiplex RT-PCR to detect foot-and-mouth disease virus in tissue and food samples," Archives of Virology, vol. 153, no. 1, pp. 205-209, 2008.

[151] J. Fernández, M. Agüero, L. Romero et al., "Rapid and differential diagnosis of foot-and-mouth disease, swine vesicular disease, and vesicular stomatitis by a new multiplex RT-PCR assay," Journal of Virological Methods, vol. 147, no. 2, pp. 301311, 2008.

[152] B. J. Hindson, S. M. Reid, B. R. Baker et al., "Diagnostic evaluation of multiplexed reverse transcription-PCR microsphere array assay for detection of foot-and-mouth and lookalike disease viruses," Journal of Clinical Microbiology, vol. 46, no. 3, pp. 1081-1089, 2008.

[153] E. M. Elnifro, A. M. Ashshi, R. J. Cooper, and P. E. Klapper, "Multiplex PCR: optimization and application in diagnostic virology," Clinical Microbiology Reviews, vol. 13, no. 4, pp. 559-570, 2000.
[154] S. Tam, A. Clavijo, E. K. Engelhard, and M. C. Thurmond, "Fluorescence-based multiplex real-time RT-PCR arrays for the detection and serotype determination of foot-and-mouth disease virus," Journal of Virological Methods, vol. 161, no. 2, pp. 183-191, 2009.

[155] N. F. Lomakina, F. Fallacara, M. Pacciarini et al., "Application of universal primers for identification of Foot-and-mouth disease virus and Swine vesicular disease virus by PCR and PCR-ELISA," Archives of Virology, vol. 149, no. 6, pp. 11551170, 2004.

[156] I. M. Mackay, K. E. Arden, and A. Nitsche, "Real-time PCR in virology," Nucleic Acids Research, vol. 30, no. 6, pp. 12921305, 2002.

[157] B. Hoffmann, M. Beer, S. M. Reid et al., "A review of RT-PCR technologies used in veterinary virology and disease control: sensitive and specific diagnosis of five livestock diseases notifiable to the World Organisation for Animal Health," Veterinary Microbiology, vol. 139, no. 1-2, pp. 1-23, 2009.

[158] I. A. Nazarenko, S. K. Bhatnagar, and R. J. Hohman, "A closed tube format for amplification and detection of DNA based on energy transfer," Nucleic Acids Research, vol. 25, no. 12, pp. 2516-2521, 1997.

[159] B. Schweiger, I. Zadow, R. Heckler, H. Timm, and G. Pauli, "Application of a fluorogenic PCR assay for typing and subtyping of influenza viruses in respiratory samples," Journal of Clinical Microbiology, vol. 38, no. 4, pp. 1552-1558, 2000.

[160] E. M. Black, J. P. Lowings, J. Smith, P. R. Heaton, and L. M. McElhinney, "A rapid RT-PCR method to differentiate six established genotypes of rabies and rabies-related viruses using TaqMan technology," Journal of Virological Methods, vol. 105, no. 1, pp. 25-35, 2002.

[161] J. D. Callahan, F. Brown, F. A. Osorio et al., "Use of a portable real-time reverse transcriptase-polymerase chain reaction assay for rapid detection of foot-and-mouth disease virus," Journal of the American Veterinary Medical Association, vol. 220, no. 11, pp. 1636-1642, 2002.

[162] S. A. Bustin, "Absolute quantification of mrna using realtime reverse transcription polymerase chain reaction assays," Journal of Molecular Endocrinology, vol. 25, no. 2, pp. 169193, 2000.

[163] S. A. Bustin, V. Benes, T. Nolan, and M. W. Pfaffl, "Quantitative real-time RT-PCR-a perspective," Journal of Molecular Endocrinology, vol. 34, no. 3, pp. 597-601, 2005.

[164] T. Morris, B. Robertson, and M. Gallagher, "Rapid reverse transcription-PCR detection of hepatitis $\mathrm{C}$ virus RNA in serum by using the TaqMan fluorogenic detection system," Journal of Clinical Microbiology, vol. 34, no. 12, pp. 29332936, 1996.

[165] H. H. Kessler, G. Mühlbauer, B. Rinner et al., "Detection of herpes simplex virus DNA by real-time PCR," Journal of Clinical Microbiology, vol. 38, no. 7, pp. 2638-2642, 2000.

[166] K. U. O. Jae, J. K. Soo, N. L. Kwang et al., "Development of synthetic peptide ELISA based on nonstructural protein $2 \mathrm{C}$ of foot and mouth disease virus," Journal of Veterinary Science, vol. 6, no. 4, pp. 317-325, 2005.

[167] M. Moniwa, A. Clavijo, M. Li, B. Collignon, and R. P. Kitching, "Performance of a foot-and-mouth disease virus reverse transcription polymerase chain reaction with amplification controls between three real-time instruments," The Journal of Veterinary Diagnostic Investigation, vol. 19, pp. 9-20, 2007.

[168] T. B. Rasmussen, Å. Uttenthal, K. de Stricker, S. Belak, and T. Storgaard, "Development of a novel quantitative real-time RT-PCR assay for the simultaneous detection of all serotypes 
of Foot-and-mouth disease virus," Archives of Virology, vol. 148, no. 10, pp. 2005-2021, 2003.

[169] S. M. Reid, S. S. Grierson, N. P. Ferris, G. H. Hutchings, and S. Alexandersen, "Evaluation of automated RT-PCR to accelerate the laboratory diagnosis of foot-and-mouth disease virus," Journal of Virological Methods, vol. 107, no. 2, pp. 129-139, 2003.

[170] S. M. Reid, N. P. Ferris, A. Brüning, G. H. Hutchings, Z. Kowalska, and L. Åkerbolm, "Development of a rapid chromatographic strip test for the pen-side detection of foot-and-mouth disease virus antigen," Journal of Virological Methods, vol. 96, no. 2, pp. 189-202, 2001.

[171] M. B. Oleksiewicz, A. I. Donaldson, and S. Alexandersen, "Development of a novel real-time RT-PCR assay for quantitation of foot-and-mouth disease virus in diverse porcine tissues," Journal of Virological Methods, vol. 92, no. 1, pp. 2325, 2001.

[172] S. Alexandersen, M. B. Oleksiewicz, and A. I. Donaldson, "The early pathogenesis of foot-and-mouth disease in pigs infected by contact: a quantitative time-course study using TaqMan RT-PCR," Journal of General Virology, vol. 82, no. 4, pp. 747-755, 2001.

[173] S. Alexandersen, Z. Zhang, and A. I. Donaldson, "Aspects of the persistence of foot-and-mouth disease virus in animalsthe carrier problem," Microbes and Infection, vol. 4, no. 10, pp. 1099-1110, 2002.

[174] S. Alexandersen, Z. Zhang, A. I. Donaldson, and A. J. M. Garland, "The pathogenesis and diagnosis of foot-andmouth disease," Journal of Comparative Pathology, vol. 129, no. 1, pp. 1-36, 2003.

[175] Z. Zhang and S. Alexandersen, "Detection of carrier cattle and sheep persistently infected with foot-and-mouth disease virus by a rapid real-time RT-PCR assay," Journal of Virological Methods, vol. 111, no. 2, pp. 95-100, 2003.

[176] P. V. Barnett, P. Keel, S. Reid et al., "Evidence that high potency foot-and-mouth disease vaccine inhibits local virus replication and prevents the "carrier" state in sheep," Vaccine, vol. 22, no. 9-10, pp. 1221-1232, 2004.

[177] S. J. Cox, C. Voyce, S. Parida et al., "Protection against directcontact challenge following emergency FMD vaccination of cattle and the effect on virus excretion from the oropharynx," Vaccine, vol. 23, no. 9, pp. 1106-1113, 2005.

[178] N. P. Ferris, D. P. King, S. M. Reid et al., "Foot-and-mouth disease virus: a first inter-laboratory comparison trial to evaluate virus isolation and RT-PCR detection methods," Veterinary Microbiology, vol. 117, no. 2-4, pp. 130-140, 2006.

[179] S. M. Reid, S. Parida, D. P. King et al., "Utility of automated real-time RT-PCR for the detection of foot-and-mouth disease virus excreted in milk," Veterinary Research, vol. 37, no. 1, pp. 121-132, 2006.

[180] D. J. Sammin, D. J. Paton, S. Parida et al., "Evaluation of laboratory tests for SAT serotypes of foot-and-mouth disease virus with specimens collected from convalescent cattle in Zimbabwe," Veterinary Record, vol. 160, no. 19, pp. 647-654, 2007.

[181] A. E. Shaw, S. M. Reid, D. P. King, G. H. Hutchings, and N. P. Ferris, "Enhanced laboratory diagnosis of foot and mouth disease by real-time polymerase chain reaction," Revue Scientifique et Technique (International Office of Epizootics), vol. 23, no. 3, pp. 1003-1009, 2004.

[182] K. Persson, K. Hamby, and L. A. Ugozzoli, "Four-color multiplex reverse transcription polymerase chain reactionovercoming its limitations," Analytical Biochemistry, vol. 344, no. 1, pp. 33-42, 2005.
[183] S. Belak, "Molecular diagnosis of viral diseases, present trends and future aspects. A view from the OIE Collaborating Centre for the Application of Polymerase Chain Reaction Methods for Diagnosis of Viral Diseases in Veterinary Medicine," Vaccine, vol. 25, no. 30, pp. 5444-5452, 2007.

[184] M. J. Espy, J. R. Uhl, L. M. Sloan et al., "Real-time PCR in clinical microbiology: applications for routine laboratory testing," Clinical Microbiology Reviews, vol. 19, no. 1, pp. 165256, 2006.

[185] E. Silberstein, G. Kaplan, O. Taboga, S. Duffy, and E. Palma, "Foot-and-mouth disease virus-infected but not vaccinated cattle develop antibodies against recombinant $3 \mathrm{AB} 1$ nonstructural protein," Archives of Virology, vol. 142, no. 4, pp. 795-805, 1997.

[186] M. Nanni, M. Alegre, D. Compaired, O. Taboga, and N. Fondevila, "Novel purification method for recombinant $3 \mathrm{AB} 1$ nonstructural protein of foot-and-mouth disease virus for use in differentiation between infected and vaccinated animals," Journal of Veterinary Diagnostic Investigation, vol. 17, no. 3, pp. 248-251, 2005.

[187] V. V. S. Suryanarayana, S. Viswanathan, G. Ratish et al., "E. coli expressed proteins as diagnostic reagents for typing of foot-and-mouth disease virus," Archives of Virology, vol. 144, no. 9, pp. 1701-1712, 1999.

[188] M. Latha Priyadharshini, V. Balamurugan, K. Prabhudas, V. V. S. Suryanarayana, and G. R. Reddy, "Expression of $3 \mathrm{AB}$ protein of foot and mouth disease virus in Pichia pastoris," Indian Journal of Biotechnology, vol. 6, no. 3, pp. 329-335, 2007.

[189] U. Bruderer, H. Swam, B. Haas et al., "Differentiating infection from vaccination in foot-and-mouth-disease: evaluation of an ELISA based on recombinant 3ABC," Veterinary Microbiology, vol. 101, no. 3, pp. 187-197, 2004.

[190] Z. Lu, Y. Cao, J. Guo et al., "Development and validation of a $3 \mathrm{ABC}$ indirect ELISA for differentiation of foot-and-mouth disease virus infected from vaccinated animals," Veterinary Microbiology, vol. 125, no. 1-2, pp. 157-169, 2007.

[191] V. Balamurugan, R. Renji, S. N. Saha, G. R. Reddy, S. Gopalakrishna, and V. V. S. Suryanarayana, "Protective immune response of the capsid precursor polypeptide (P1) of foot and mouth disease virus type 'O' produced in Pichia pastoris," Virus Research, vol. 92, no. 2, pp. 141-149, 2003.

[192] V. Balamurugan, R. Renji, G. Venkatesh et al., "Protective immune response against foot-and-mouth disease virus challenge in guinea pigs vaccinated with recombinant P1 polyprotein expressed in Pichia pastoris," Archives of Virology, vol. 150, no. 5, pp. 967-979, 2005.

[193] R. Renji, V. Balamurugan, S. N. Saha, G. R. Reddy, and V. V. S. Suryanarayana, "Expression of capsid precursor polypeptide (P1) of foot and mouth disease virus vaccine strains in pichia pastoris," Indian Journal of Biotechnology, vol. 2, no. 4, pp. 533-538, 2003.

[194] Y. J. Ko, H. Y. Jeoung, H. S. Lee et al., "A recombinant protein-based ELISA for detecting antibodies to foot-andmouth disease virus serotype Asia 1," Journal of Virological Methods, vol. 159, no. 1, pp. 112-118, 2009.

[195] Å. Uttenthal, S. Parida, T. B. Rasmussen, D. J. Paton, B. Haas, and W. G. Dundon, "Strategies for differentiating infection in vaccinated animals (DIVA) for foot-andmouth disease, classical swine fever and avian influenza," Expert Review of Vaccines, vol. 9, no. 1, pp. 73-87, 2010.

[196] L. M. Henderson, "Overview of marker vaccine and differential diagnostic test technology," Biologicals, vol. 33, no. 4, pp. 203-209, 2005. 
[197] M. J. Grubman, "Development of novel strategies to control foot-and-mouth disease: marker vaccines and antivirals," Biologicals, vol. 33, no. 4, pp. 227-234, 2005.

[198] V. L. Fowler, N. J. Knowles, D. J. Paton, and P. V. Barnett, "Marker vaccine potential of a foot-and-mouth disease virus with a partial VP1 G-H loop deletion," Vaccine, vol. 28, no. 19, pp. 3428-3434, 2010.

[199] J. G. Hacia and F. S. Collins, "Mutational analysis using oligonucleotide microarrays," Journal of Medical Genetics, vol. 36, no. 10, pp. 730-736, 1999.

[200] S. V. Tillib and A. D. Mirzabekov, "Advances in the analysis of DNA sequence variations using oligonucleotide microchip technology," Current Opinion in Biotechnology, vol. 12, no. 1, pp. 53-58, 2001.

[201] H. Matsuzaki, S. Dong, H. Loi et al., "Genotyping over 100,000 SNPs on a pair of oligonucleotide arrays," Nat Methods, vol. 1, no. 2, pp. 109-111, 2004.

[202] D. Wang, L. Coscoy, M. Zylberberg et al., "Microarray-based detection and genotyping of viral pathogens," Proceedings of the National Academy of Sciences of the United States of America, vol. 99, no. 24, pp. 15687-15692, 2002.

[203] W. H. Long, H. S. Xiao, X. M. Gu et al., "A universal microarray for detection of SARS coronavirus," Journal of Virological Methods, vol. 121, no. 1, pp. 57-63, 2004.

[204] B. Lin, G. J. Vora, D. Thach et al., "Use of oligonucleotide microarrays for rapid detection and serotyping of acute respiratory disease-associated adenoviruses," Journal of Clinical Microbiology, vol. 42, no. 7, pp. 3232-3239, 2004.

[205] P. A. Bryant, D. Venter, R. Robins-Browne, and N. Curtis, "Chips with everything: DNA microarrays in infectious diseases," The Lancet Infectious Diseases, vol. 4, no. 2, pp. 100$111,2004$.

[206] H. M. Striebel, E. Birch-Hirschfeld, R. Egerer, and Z. Földes-Papp, "Virus diagnostics on microarrays," Current Pharmaceutical Biotechnology, vol. 4, no. 6, pp. 401-415, 2003.

[207] C. M. Fauquet, M. A. Mayo, J. Maniloff, U. Desselberger, and L. A. Ball, Virus Taxonomy. Eigth Report of the International Committee on Taxonomy of Viruses, Elsevier, San Diego, Calif, USA, 2005.

[208] E. Domingo, "Quasispecies: concept and implications for virology," Current Topics in Microbiology and Immunology, vol. 299, 2006.

[209] E. Domingo, C. Biebricher, M. Eigen, and J. J. Holland, Quasispecies and RNA Virus Evolution: Principles and Consequences, Landes Bioscience, Austin, Tex, USA, 2001.

[210] E. Baranowski, C. M. Ruiz-Jarabo, N. Pariente, N. Verdaguer, and E. Domingo, "Evolution of cell recognition by viruses: a source of biological novelty with medical implications," Advances in Virus Research, vol. 62, pp. 19-111, 2003.

[211] M. K. Baxi, S. Baxi, A. Clavijo, K. M. Burton, and D. Deregt, "Microarray-based detection and typing of foot-and-mouth disease virus," Veterinary Journal, vol. 172, no. 3, pp. 473-481, 2006.

[212] V. Martín, C. Perales, D. Abia, A. R. Ortíz, E. Domingo, and C. Briones, "Microarray-based identification of antigenic variants of foot-and-mouth disease virus: a bioinformatics quality assessment," BMC Genomics, vol. 7, article 117, 2006.

[213] M. R. Gajendragad, K. N. Y. Kamath, P. Y. Anil, K. Prabhudas, and C. Natarajan, "Development and standardization of a piezo electric immunobiosensor for foot and mouth disease virus typing," Veterinary Microbiology, vol. 78, no. 4, pp. 319$330,2001$.
[214] R. M. Ferraz, A. Arís, M. A. Martínez, and A. Villaverde, "High-throughput, functional screening of the anti-HIV-1 humoral response by an enzymatic nanosensor," Molecular Immunology, vol. 43, no. 13, pp. 2119-2123, 2006.

[215] R. M. Ferraz, M. A. Martínez, R. Cubarsi, and A. Villaverde, "Antiretroviral therapy-induced functional modification of IgG4 and IgM responses in HIV-1-infected individuals screened by an allosteric biosensor," Journal of Biomolecular Screening, vol. 13, no. 8, pp. 817-821, 2008.

[216] F. Villinger, H. K. Mueller, L. Bruckner, M. Ackermann, and U. Kihm, "Antibodies to foot-and-mouth disease virus infection associated (VIA) antigen: use of a bioengineered VIA protein as antigen in an ELISA," Veterinary Microbiology, vol. 20, no. 3, pp. 235-246, 1989.

[217] A. Villaverde, "Allosteric enzymes as biosensors for molecular diagnosis," The FEBS Letters, vol. 554, no. 1-2, pp. 169-172, 2003.

[218] R. M. Ferraz, A. Vera, A. Arís, and A. Villaverde, "Insertional protein engineering for analytical molecular sensing," Microbial Cell Factories, vol. 5, article 15, 2006.

[219] A. Benito and M. H. V. Van Regenmortel, "Biosensor characterization of antigenic site A of foot-and-mouth disease virus presented in different vector systems," FEMS Immunology and Medical Microbiology, vol. 21, no. 2, pp. 101-115, 1998.

[220] J. X. Feliu, N. Ferrer-Miralles, E. Blanco, D. Cazorla, F. Sobrino, and A. Villaverde, "Enhanced response to antibody binding in engineered $\beta$-galactosidase enzymatic sensors," Biochimica et Biophysica Acta, vol. 1596, no. 2, pp. 212-224, 2002.

[221] M. T. Sánchez-Aparicio, M. F. Rosas, R. M. Ferraz et al., "Discriminating foot-and-mouth disease virus-infected and vaccinated animals by use of $\beta$-galactosidase allosteric biosensors," Clinical and Vaccine Immunology, vol. 16, no. 8, pp. 1228-1235, 2009.

[222] R. G. McFarlane, T. W. Molitor, and V. N. Vakharia, "The detection and differentiation of foot-and-mouth disease viruses using solid-phase nucleic acid hybridization," Journal of Virological Methods, vol. 27, no. 2, pp. 175-188, 1990.

[223] L. T. Lau, S. M. Reid, D. P. King et al., "Detection of footand-mouth disease virus by nucleic acid sequence-based amplification (NASBA)," Veterinary Microbiology, vol. 126, no. 1-3, pp. 101-110, 2008.

[224] Y. J. Kim, F. Lebreton, C. Kaiser, C. Crucière, and M. Rémond, "Isolation of foot-and-mouth disease virus specific bovine antibody fragments from phage display libraries," Journal of Immunological Methods, vol. 286, no. 1-2, pp. 155-166, 2004.

[225] Y. Al, J. Anderson, C. Chard-Bergstrom, and S. Kapil, "Development, evaluation, and application of lateral-flow immunoassay (immunochromatography) for detection of Rotavirus in Bovine Fecal samples," Clinical and Diagnostic Laboratory Immunology, vol. 9, no. 3, pp. 723-724, 2002.

[226] A. Brüning, K. Bellamy, D. Talbot, and J. Anderson, "A rapid chromatographic strip test for the pen-side diagnosis of rinderpest virus," Journal of Virological Methods, vol. 81, no. 1-2, pp. 143-154, 1999.

[227] K. Kameyama, Y. Sakoda, K. Tamai et al., "Development of an immunochromatographic test kit for rapid detection of bovine viral diarrhea virus antigen," Journal of Virological Methods, vol. 138, no. 1-2, pp. 140-146, 2006.

[228] N. P. Ferris, A. Nordengrahn, G. H. Hutchings et al., "Development and laboratory validation of a lateral flow device for the detection of foot-and-mouth disease virus in clinical samples," Journal of Virological Methods, vol. 155, no. 1, pp. 10-17, 2009. 
[229] N. P. Ferris, A. Nordengrahn, G. H. Hutchings et al., "Development and laboratory validation of a lateral flow device for the detection of serotype SAT 2 foot-and-mouth disease viruses in clinical samples," Journal of Virological Methods, vol. 163, no. 2, pp. 474-476, 2010.

[230] T. Jiang, Z. Liang, W.-W. Ren et al., "A simple and rapid colloidal gold-based immunochromatogarpic strip test for detection of FMDV serotype A," Virologica Sinica, vol. 26, no. 1, pp. 30-39, 2011.

[231] T. Notomi, H. Okayama, H. Masubuchi et al., "Loopmediated isothermal amplification of DNA," Nucleic Acids Research, vol. 28, no. 12, p. E63, 2000.

[232] D. B. Sun, R. Wu, X. J. He et al., "A novel loop-mediated isothermal amplification (LAMP) method for detection of Fusobacterium necrophorum from footrot," African Journal of Microbiology Research, vol. 4, no. 23, pp. 2617-2621, 2010.

[233] J. P. Dukes, D. P. King, and S. Alexandersen, "Novel reverse transcription loop-mediated isothermal amplification for rapid detection of foot-and-mouth disease virus," Archives of Virology, vol. 151, no. 6, pp. 1093-1106, 2006.

[234] Anonymous, "Rapid detection of Foot and Mouth Disease virus by Reverse Transcription loop mediated Isothermal amplification (RT-LAMP)," International Journal of Applied Research in Veterinary Medicine, vol. 8, no. 2, pp. 133-142, 2010. 

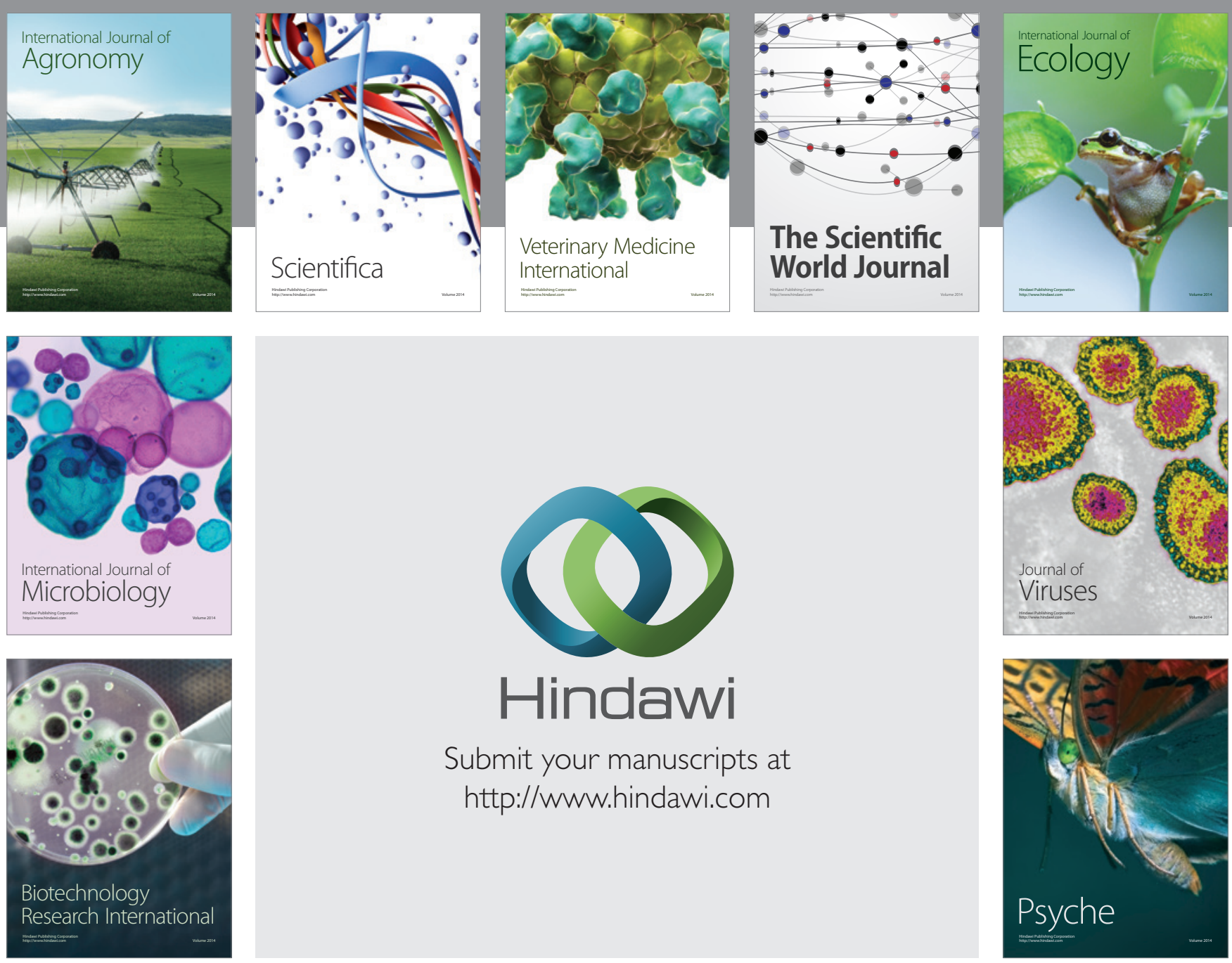

Submit your manuscripts at

http://www.hindawi.com
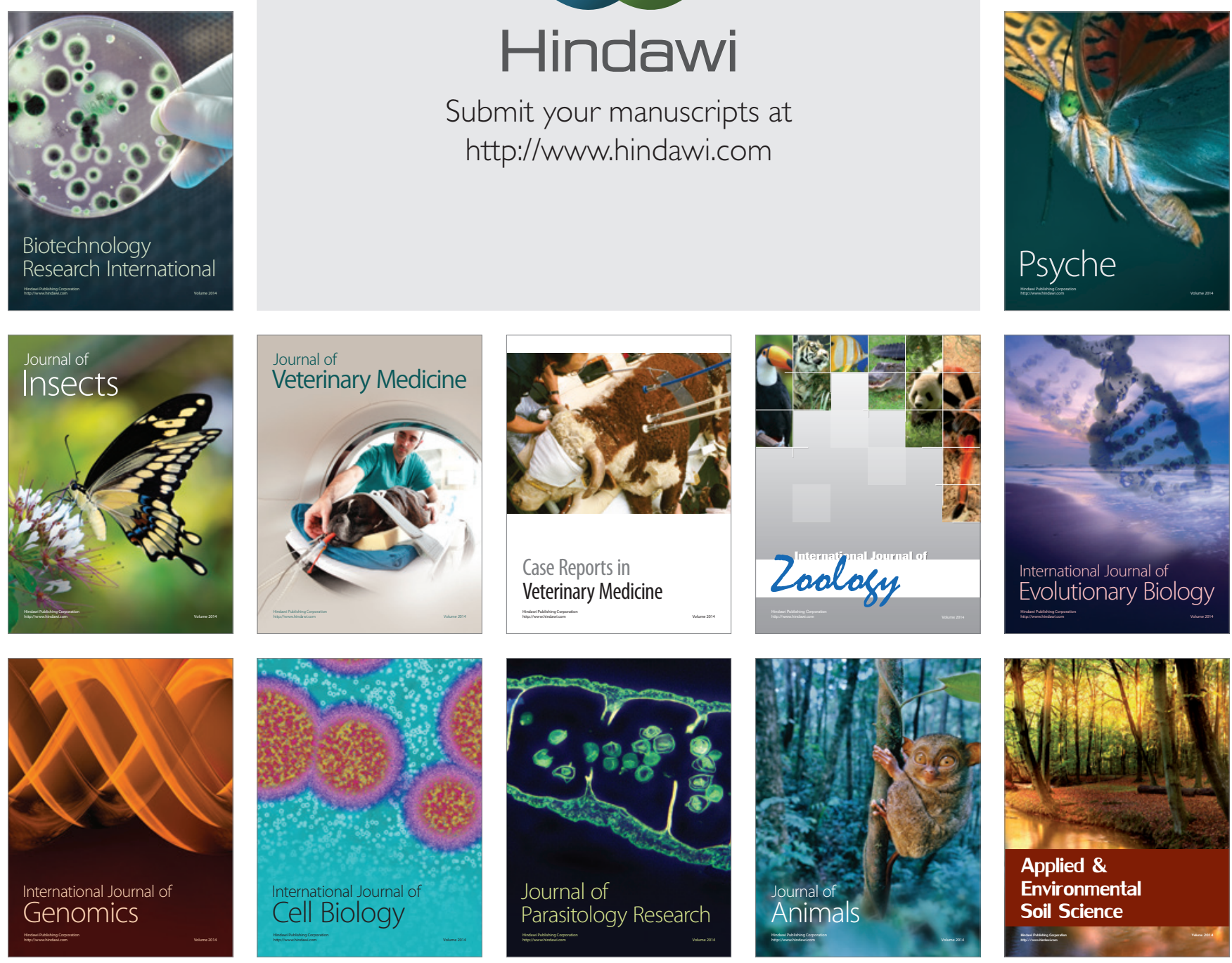